\title{
Therapeutic Interventions to Mitigate Mitochondrial Dysfunction and Oxidative Stress-Induced Damage in Patients with Bipolar Disorder
}

\author{
Sahithi Madireddy ${ }^{1, *}$ and Samskruthi Madireddy ${ }^{2}$ \\ 1 Massachusetts Institute of Technology, Cambridge, MA 02139, USA \\ 2 Department of Neuroscience, Johns Hopkins University, Baltimore, MD 21218, USA; smadire2@jhu.edu \\ * Correspondence: sahithim@mit.edu
}

Citation: Madireddy, S.; Madireddy, S. Therapeutic Interventions to Mitigate Mitochondrial Dysfunction and Oxidative Stress-Induced Damage in Patients with Bipolar Disorder. Int. J. Mol. Sci. 2022, 23 , 1844. https://doi.org/10.3390/ ijms23031844

Academic Editor: Iain P. Hargreaves

Received: 14 November 2021

Accepted: 30 December 2021

Published: 6 February 2022

Publisher's Note: MDPI stays neutral with regard to jurisdictional claims in published maps and institutional affiliations.

Copyright: (C) 2022 by the authors. Licensee MDPI, Basel, Switzerland. This article is an open access article distributed under the terms and conditions of the Creative Commons Attribution (CC BY) license (https:// creativecommons.org/licenses/by/ $4.0 /)$

\begin{abstract}
Bipolar disorder (BD) is characterized by mood changes, including recurrent manic, hypomanic, and depressive episodes, which may involve mixed symptoms. Despite the progress in neurobiological research, the pathophysiology of BD has not been extensively described to date. Progress in the understanding of the neurobiology driving BD could help facilitate the discovery of therapeutic targets and biomarkers for its early detection. Oxidative stress (OS), which damages biomolecules and causes mitochondrial and dopamine system dysfunctions, is a persistent finding in patients with BD. Inflammation and immune dysfunction might also play a role in BD pathophysiology. Specific nutrient supplements (nutraceuticals) may target neurobiological pathways suggested to be perturbed in BD, such as inflammation, mitochondrial dysfunction, and OS. Consequently, nutraceuticals may be used in the adjunctive treatment of BD. This paper summarizes the possible roles of OS, mitochondrial dysfunction, and immune system dysregulation in the onset of BD. It then discusses OS-mitigating strategies that may serve as therapeutic interventions for BD. It also analyzes the relationship between diet and BD as well as the use of nutritional interventions in the treatment of BD. In addition, it addresses the use of lithium therapy; novel antipsychotic agents, including clozapine, olanzapine, risperidone, cariprazine, and quetiapine; and anti-inflammatory agents to treat BD. Furthermore, it reviews the efficacy of the most used therapies for BD, such as cognitivebehavioral therapy, bright light therapy, imagery-focused cognitive therapy, and electroconvulsive therapy. A better understanding of the roles of OS, mitochondrial dysfunction, and inflammation in the pathogenesis of bipolar disorder, along with a stronger elucidation of the therapeutic functions of antioxidants, antipsychotics, anti-inflammatory agents, lithium therapy, and light therapies, may lead to improved strategies for the treatment and prevention of bipolar disorder.
\end{abstract}

Keywords: bipolar disorder; oxidative stress; mitochondrial dysfunctions; immune system dysregulation; nutrients; antipsychotics; anti-inflammatory agents; lithium therapy; light therapy

\section{Introduction}

Bipolar disorder (BD) is a chronic mental illness characterized by an alternation between mania or hypomania and depression [1-4]. It is often associated with impaired functionality $[5,6]$. Neurotransmitter imbalance, oxidative stress (OS), and genetic causes are some of the factors that have been linked to the pathophysiology of $\mathrm{BD}[7,8]$. A consistent finding in $\mathrm{BD}$ is the presence of $\mathrm{OS}$, which makes biomolecules susceptible to oxidative and nitrosative damage [9]. Dopamine (DA) levels are notably increased during mania, and DA produces reactive oxygen species (ROS) and quinones that can proceed to oxidize proteins [9]. The overproduction of ROS and reactive nitrogen species, along with impaired maintenance of balance by antioxidant systems, can result in damage to lipids, proteins, DNA, and RNA $[9,10]$. In addition, the presence of ROS/reactive nitrogen species in mitochondria leads to oxidation of mitochondrial DNA (mtDNA), proteins, and lipids $[10,11]$. Inflammation and immune dysfunction may be involved in BD pathophysiology [12-17]. 
This review focuses on the roles of ROS and ROS-induced oxidative damage, mitochondrial dysfunction, DNA damage, and DA system dysregulation, and immune dysfunction in the pathophysiology of BD. It also presents an overview of potential biomarkers, including lipid peroxidation, thiobarbituric acid reactive substances (TBARSs), and brain-derived neurotrophic factor (BDNF), in patients with BD.

Diet influences several processes that are dysregulated in $\mathrm{BD}$, including monoaminergic activity, inflammation and immune processes, OS, mitochondrial function, and neuroprogression. Therefore, in this review, we also discuss the possible use of nutrients, including vitamin D, copper, folic acid, and polyunsaturated fatty acids (PUFAs), in the treatment of patients with BD. In addition to nutraceutical approaches, we further discuss the use of anti-inflammatory agents and novel antipsychotic agents, such as clozapine, olanzapine, risperidone, cariprazine, and quetiapine, as alternatives to lithium or conventional antipsychotic agents. Furthermore, we assess the use of therapies, such as cognitivebehavioral therapy (CBT), bright light therapy (BLT), imagery-focused cognitive therapy $(\operatorname{ImCT})$, and electroconvulsive therapy $(\mathrm{ECT})$, to treat $\mathrm{BD}$.

\section{BD}

$\mathrm{BD}$ is one of the most debilitating psychiatric disorders, and it involves abnormal neuroplasticity [18-24]. It is defined by disruptive depressive and manic or hypomanic episodes [25-32]. The two main categories of BD are type I (BD-I) and type II (BD-II) [33,34]. BD-I is characterized by at least one manic episode, involving increased activity, libido, and grandiose thinking, followed by a hypomanic or depressive episode [35-38]. On the other hand, BD-II includes at least one hypomanic and depressive episode but does not present with manic episodes [39,40]. Despite the availability of current pharmacological and psychosocial treatments, BD can increase the risk of substance abuse, suicide, and mortality from comorbidities [41-51].

$\mathrm{BD}$ is a complex disorder involving environmental, social, and genetic factors [52,53]. Biological processes in the pathophysiology of BD include perturbations of brain development, chronobiology, and neuroplasticity; defective apoptotic, inflammatory, neurotrophic, neurotransmitter, and calcium signaling; oxidative and nitrosative stress; endoplasmic reticulum stress; as well as mitochondrial dysfunction [54-63]. As the parietal lobe supports cognition, attention, and memory, it is greatly involved in the progression of $\mathrm{BD}[39,64]$. Some patients with BD exhibit neuroprogression [65-67], which is characterized by progressive changes in neuroanatomy, including decreased hippocampal volume [68], increased lateral ventricle size [69], and decreased cortical thickness [70]. These neuroanatomical changes are associated with functional impairment. [65-70].

\section{OS}

An imbalance between antioxidative and oxidative processes leads to OS, which can produce ROS and free radicals that proceed to damage cellular components [71-73]. OS leads to not only mutations in mtDNA and damage to the electron transport chain but also changes in membrane permeability, mitochondrial defense mechanisms, and calcium levels [74]. The central nervous system is especially vulnerable to OS because the brain uses large amounts of oxygen, which increases the production of free radicals and ROS [75,76].

ROS are free radicals that contain oxygen; they form as a byproduct of electron transport [77]. They are created by the premature discharge of electrons from complexes near the start of the electron transport chain [77]. This process leads to the formation of superoxide anions $\left(\mathrm{O}_{2} \bullet^{-}\right)$. Superoxide dismutase (SOD) turns superoxide radicals to hydrogen peroxide $\left(\mathrm{H}_{2} \mathrm{O}_{2}\right)$; catalase (CAT) and glutathione peroxidase (GPX) convert $\mathrm{H}_{2} \mathrm{O}_{2}$ to water and oxygen [78-83]. Under normal conditions, $1 \%$ to $5 \%$ of the oxygen consumed by a cell forms ROS [84]; by contrast, under conditions of mitochondrial insult, such as mitochondrial toxin exposure or excess calcium, oxygen conversion to ROS is increased [77]. Excessive intake of nutrients can also produce large quantities of ROS because the electron transport chain might become overloaded with electrons, causing their 
promiscuous release $[85,86]$. Failure to eliminate ROS can lead to oxidative injury to the cell, including peroxidation of lipids, DNA, and proteins (e.g., receptors and enzymes) [87-89]. The iron-sulfur clusters involved in electron transport in complexes I and III are most vulnerable to oxidative damage [86].

DA is another factor that may contribute to OS [90]. Through spontaneous autooxidation or with enzyme catalysis, DA can easily be oxidized to form quinones and ROS [91]. This outcome produces $\mathrm{H}_{2} \mathrm{O}_{2}$, which can react with transition metals to create toxic hydroxyl radicals [91]. In addition, the electrophilic DA quinones formed by autooxidation may potentially react with thiol compounds [91]. Both ROS and quinones may proceed to damage cellular components. Moreover, the products of DA oxidation inhibit the activity of cysteine-rich proteins, such as DA transporter (DAT) [91]. Figure 1 illustrates the potential interactions between BD, OS, mitochondrial dysfunction, immune dysfunction, antioxidants, antidepressant agents, anti-inflammatory agents, antipsychotic agents, and light therapies.

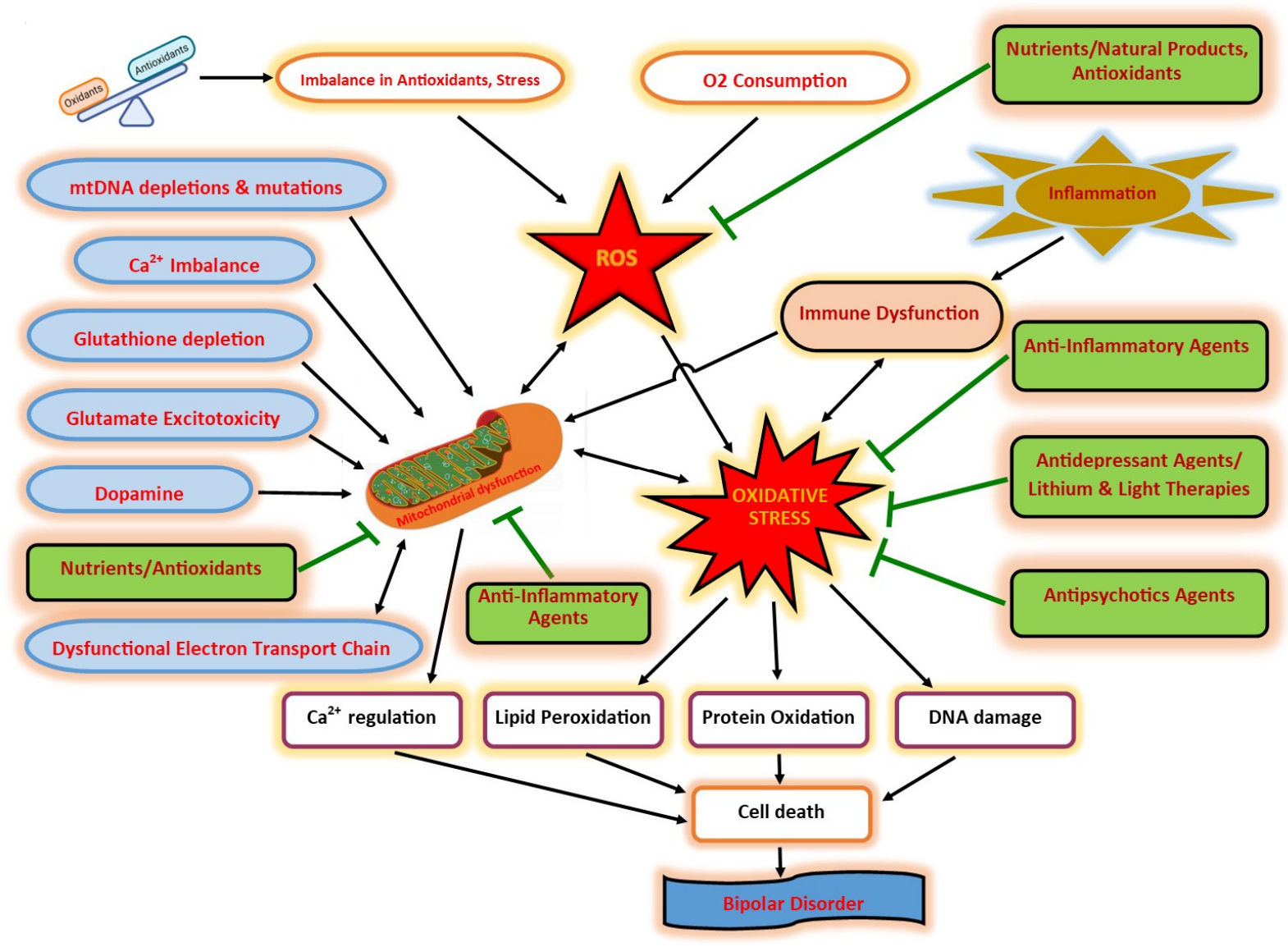

Figure 1. The potential interactions between $\mathrm{BD}, \mathrm{OS}$, mitochondrial dysfunction, immune dysfunction, antioxidants, antidepressant agents, anti-inflammatory agents, antipsychotic agents, and light therapies.

\section{Oxidative Damage in BD}

OS has been posited to play a role in the development of several psychiatric disorders, including BD [92-94]. For instance, two recent studies found increased OS in BD [93,95]. Moreover, postmortem samples of the blood and brain revealed that younger patients with BD consistently show damage from OS [96-102]. Alterations in neuroplasticity, signaling, and neurotransmitter uptake by increased OS may be involved in the pathogenesis of these dysfunctions $[103,104]$. These harmful changes may be partially a consequence of increased lipid peroxidation in membranes, proteins, and DNA due to increased OS $[105,106]$.

Such biomarkers as protein oxidation, 8-hydroxydeoxyguanosine, and lipid peroxidation can indicate the extent of oxidative damage [107,108]. Increased lipid peroxidation 
has been observed in the prefrontal cortex and anterior cingulate cortex of patients with BD [109]. Moreover, in their meta-analysis, Brown et al. reported increased lipid peroxidation and damage to DNA and RNA in BD [110]. Another meta-analysis of 27 articles, encompassing 971 patients with BD and 886 healthy controls, found significantly higher lipid peroxidation, nitric oxide, and damage to DNA and RNA in patients with BD compared with controls [110]. These findings support the potential role of OS in BD pathogenesis, particularly through its effects on lipids, DNA, and RNA [110,111].

Other measures of OS are total antioxidant status (TAS), total oxidant status (TOS), and OS index, which indicates the balance between oxidation and antioxidation [107]. The total activity of antioxidants is demonstrated by TAS, whereas that of ROS is demonstrated by TOS. The OS index is determined by the ratio of TOS to TAS, and this reflects the overall OS level [107]. One study conducted with 94 BD patients and 41 healthy controls reported higher TAS, TOS, and OS index levels in the BD patients compared with the controls [73]. It also investigated how differences in these measures depended on the type of BD. TAS was negatively correlated with the number of episodes a patient experienced, especially in BD-I. In addition, TOS seemed to be higher in BD-I than in BD-II [73]. The increased TAS in $\mathrm{BD}$ patients in said study may be a response to increased levels of oxidation. The same observation was reported by Yumru et al., who found higher TAS levels in the serum of BD patients who were euthymic compared with healthy controls [73].

TBARSs, carbonyl proteins, malondialdehyde (MDA), and nitrites have also been used as peripheral markers of OS. Additional antioxidant markers include total antioxidative capacity; measures of antioxidants (glutathione, zinc, and uric acid); as well as levels of SOD, GPX, and glutathione $S$-transferase [94,112]. A study of $113 \mathrm{BD}$ patients who were euthymic and 78 controls found decreased TBARS, MDA, and total antioxidative capacity levels in the BD patients compared with the controls [94]. It also found decreased antioxidant and OS markers; however, many other studies have reported the opposite finding. For example, some studies observed increased TBARS levels during mania, depression, and remission [113], implying that OS may be stable throughout the course of BD [88]. Another study corroborated this finding of increased serum TBARS levels in BD patients during mania, depression, and euthymia [114]. Moreover, Sowa-Kućma et al. found a significant positive association between higher TBARS level and severity of BD, including the risk of suicidality [115].

As specified earlier, a frequent finding in patients with $\mathrm{BD}$ is the increase in antioxidant marker levels [116], which is likely part of a compensatory response to prevent oxidative damage. Yumru et al. found that serum SOD (an antioxidant marker) was significantly elevated in patients with depression and mania compared with controls [73]. Furthermore, Andreazza et al. reported a significant increase in glutathione $S$-transferase and glutathione reductase in late-stage BD patients [117]. A meta-analysis of 44 studies, covering $1979 \mathrm{BD}$ patients and 1788 controls, found that $\mathrm{BD}$ was correlated with elevated CAT, glutathione $S$-transferase, nitrite, TBARS, MDA, and uric acid levels [112]. In addition, BD was correlated with a decrease in glutathione; changes in GPX, SOD, and zinc levels were not observed [112]. Uric acid and TBARSs were increased in patients who were manic; moreover, TBARSs were increased in patients during depression, and uric acid was increased in patients during euthymia [112].

Other researchers have also examined how OS and antioxidant markers vary over the phases of BD. Some of them observed that TBARS and SOD levels in BD patients who were experiencing manic and depressive episodes were higher than those in BD patients who were euthymic and those in controls $[95,118]$. Similarly, Kunz et al. found that SOD activity was only elevated in acute BD and did not significantly differ between controls and BD patients who were euthymic [118]. As mentioned previously, elevated SOD levels may be part of a compensatory response to excess ROS production during an acute phase of $\mathrm{BD}$. This overproduction would mobilize antioxidant defenses and systems of neuronal plasticity [81]. Consistent with the findings of Kunz et al., Andreazza et al. [119] and Machado-Vierra et al. [95] reported higher SOD levels and higher CAT 
and SOD levels, respectively, in BD patients who were manic compared with controls. However, Gergerlioglu et al. found that BD patients had decreased SOD levels during manic episodes [120].

Several key findings regarding how OS mechanisms can contribute to BD have been reported. Excess ROS can damage mitochondria through mutations to mtDNA, thereby damaging the electron transport chain and altering membrane permeability [74,121,122]. ROS overproduction can also damage proteins that regulate calcium, such as gated calcium channels, calcium ion $\left(\mathrm{Ca}^{2+}\right)$-ATP synthases, and proteins in the electron transport chain [74]. This outcome disrupts calcium homeostasis, leading to elevated calcium [74]. SOD and glutathione are key components of the antioxidant defense against OS [72,123]. Therefore, increased SOD activity may be seen as a mechanism of mitigating increased oxidative damage in $\mathrm{BD}$ [81].

On the other hand, increased SOD and CAT levels could also cause increased $\mathrm{H}_{2} \mathrm{O}_{2}$ production, which may contribute to neural damage through oxidation of lipids and proteins $[124,125]$. Levels of uric acid in BD patients undergoing mania have been found to be higher than those in $\mathrm{BD}$ patients undergoing depression but not those in BD patients undergoing euthymia [112]. Differences in TBARS levels between mania and depression have not been observed [112]. Compared with healthy controls, BD patients who were not taking medication have been reported to exhibit increased SOD levels and decreased GPX levels. BD patients and healthy controls have been found to demonstrate comparable SOD and GPX levels after treatment. Overall, BD is correlated with OS, uric acid/TBARS levels are increased in specific phases, and treatment may restore SOD and GPX to normal levels $[112,126]$.

\section{Mitochondrial Dysfunction}

Mitochondria are responsible for energy production and providing substrates for cell growth. In addition, they are involved in cell resilience and oxidative/nitrosative stress [127-131]. Mitochondria in the brain are important for influencing neural activity, neural plasticity, and behavioral adaptation through their effects on long-term potentiation [132-136]. Mitochondrial dysfunction has been shown to be crucial in BD [137-143]. BD may include underlying mitochondrial dysfunction based on observations of decreased cellular respiration, altered mitochondrial structure, mtDNA mutations, and decreased production of proteins involved in respiration $[54,87]$. Failure of respiration is further evidenced by a decrease in $\mathrm{pH}$ and decreased presence of compounds containing high-energy phosphates in the brain [54,87].

Moreover, mitochondrial disorders may lead to psychotic, affective, and cognitive symptoms [54,87]. Genetic, postmortem, and molecular studies have indicated that mitochondrial dysregulation could lead to the nervous system impairment observed in BD [144]. Some patients with BD have been found to exhibit deterioration in mitochondrial quality control mechanisms [141]. In addition, postmortem analyses of the brains of patients with $\mathrm{BD}$ have found decreased expression of genes involved in the electron transport chain [145]. As noted previously, BD is also associated with mutations and polymorphisms of mtDNA [146-150]. Because it lacks the protection of histones, mtDNA is especially vulnerable to mutations from oxidative damage [53]. Mitochondrial dysfunction increases ROS generation, which leads to greater OS [151]. Consistent with this reasoning, OS markers have been reported to be increased in the brains of BD patients analyzed postmortem as well as in the blood of BD patients [91,152]. Mitochondrial dysfunction may also play a role in the altered calcium signaling observed in BD [153,154].

\section{DNA Damage}

OS can cause DNA damage, which some studies on patients with BD have observed $[74,155,156]$. A significant association between DNA damage and BD as well as associations between DNA damage and the severity of BD and depressive symptoms have been reported [157]. In particular, Andreazza et al. showed a positive correlation 
between DNA damage and the severity of manic and depressive symptoms [113]. With the use of comet assay to evaluate DNA damage, they observed increased DNA damage in $\mathrm{BD}$ patients compared with controls [113]. Another study characterized the OS profile of monozygotic twins who were experiencing manic episodes [81]. Compared with healthy twins, bipolar twins had elevated SOD, TBARS, and DNA damage [81]. The bipolar twins also had decreased CAT levels. After treatment with mood stabilizers, TBARSs and SOD in the bipolar twins returned to normal levels; however, CAT levels and DNA damage were still abnormal 6 weeks after the treatment started [93]. In a rat model of mania, amphetamine administration increased DNA damage in the blood and hippocampus [81], and DNA damage was positively correlated with lipid peroxidation [89].

\section{BDNF}

BDNF is important for the development, plasticity, and survival of neurons $[75,158,159]$. Six meta-analyses found decreased BDNF levels in BD patients compared with both healthy individuals and patients with unipolar depression [52,160-163]. Lowered BDNF levels were observed with both mania and depression in BD [52,160-163]. Patients with BD may have abnormal plasma levels of other neurotrophins as well [75]. The link between higher levels of OS and decreased BDNF levels has been well demonstrated in BD [54,81].

In addition, a connection between mitochondrial complex I dysfunction, ROS production, and decreased BDNF level has been established [164]. A study of 59 BD patients and 26 healthy controls examined the association of BDNF levels with antioxidant defenses [165]. It found that the peripheral BDNF level in BD was correlated with antioxidant enzyme activity [165]. Another study also found a negative correlation between TBARS and BDNF levels in patients with BD, implying that a modified oxidative status might lead to decreased BDNF levels [166]. A meta-analysis demonstrated substantial reductions in peripheral BDNF levels in manic and depressive episodes of BD [163]. A similar metaanalysis consisting of 35 studies and 3798 research participants reported that BD patients exhibited lower peripheral BDNF levels compared with healthy controls [52]. Another study measured mtDNA copy number in leukocytes, plasma BDNF level, and antioxidant enzyme activity in $97 \mathrm{BD}$ patients and 31 healthy controls [158]. BDNF level, mtDNA copy number, and GPX activity in the BD patients were significantly lower than those in the controls [158]. Other researchers have examined the association between plasma BDNF level and the functions of GPX and SOD in BD patients and healthy controls [165]. Peripheral BDNF level in BD and antioxidant enzyme activity had a robust correlation regulated by metabolic comorbidities [165]. Overall, these findings suggest that a lowered BDNF level may be a component of the pathophysiology of BD $[52,160]$.

\section{Roles of DA and DAT in BD}

DAT is critical to the dopaminergic system due to its function in DA reuptake, causing its removal from the synaptic cleft [91]. Recent studies have highlighted a possible link between DAT and mania [91]. The enhanced dopaminergic transmission accompanying mania can contribute to OS in patients with BD $[89,167]$. Elevated DA causes a significant increase in ROS production and mitochondrial dysfunction, which may further damage DNA and cause cell death $[91,168]$. OS can induce posttranslational modifications of the DAT, which would decrease DA reuptake [91]. Because patients with BD have lower levels of antioxidant enzymes [169], they may be highly vulnerable to DAT oxidation [170]. Toxicity from increased DA can kill dopaminergic neurons, potentially resulting in the depressive phase of BD [167]. Notably, pharmaceutical therapies for BD, including $N$ acetylcysteine and lithium, may protect against OS and DA toxicity [171-173], pointing to the possibility of preventing the vicious cycle of DA inhibiting the DAT [91]. Therefore, understanding DA dysregulation in $\mathrm{BD}$ will help determine the pathophysiology of $\mathrm{BD}$ and may assist in the development of novel therapeutic agents to augment treatment [91]. 


\section{Immune Dysfunction}

BD development may be triggered by immune system dysregulation [16,174-176] such as acute-phase protein and cytokine alterations, which can cause BD through neurotransmitterand neuropeptide-related effects $[177,178]$. Proinflammatory cytokines include interleukin (IL)-6 and tumor necrosis factor-alpha (TNF- $\alpha$ ), whereas anti-inflammatory cytokines include IL-10 and IL-4, which can prevent immune system activation [179-181]. Notably, high proinflammatory cytokine levels have been consistently observed in patients with BD, especially during acute episodes [177,180,182-184]. Moreover, patients with BD exhibit reduced anti-inflammatory cytokine levels during the manic phase [185-188]. Even genetic studies have indicated that a multitude of genes that partake in various neuroimmunological and inflammatory pathways are either up or downregulated in BD. Genetic studies have suggested that the presence of $\mathrm{BD}$ correlates with differential upregulation or downregulation of several genes involved in inflammatory and neuro-immunological pathways [189]. Circulating mtDNA and inflammation level, indicated by plasma cytokine (GM-CSF, IL-2, IL-4, and IL-6) measurements, were correlated in the patients [190]. In another study, patients with BD generally showed increased proinflammatory cytokine levels [191]. In addition, depressed patients displayed reduced plasma anti-inflammatory cytokine and increased TNF- $\alpha$ levels, suggested to play a potential role in treatment resistance [191-193]. In another study investigating the relationships between OS, cytokines, and circadian preferences, plasma IL-10, IL-6, and TNH- $\alpha$ were measured [194]. Among BD patients, there was a greater change in circadian rhythms than in controls and patients with major depressive disorder [194]. Those BD patients who had reversed day/night cycles also had lower serum IL-6, IL-10, and TBARS. This suggests that oxidative stress may affect immune function and may be correlated with CNS functions in a subset of BD patients [194]. A 2021 meta-analysis described increased IL-6, TNF- $\alpha$, and C-reactive protein (CRP) levels in patients with BD, with particularly increased TNF- $\alpha$ and CRP levels during manic and depressive episodes [195]. Another meta-analysis found elevated TNF- $\alpha$, IL-4, and soluble IL-2 and IL-6 receptor levels in patients with BD compared to healthy controls [196]. In addition, certain pieces of evidence suggest that antidepressants could reduce systemic inflammation, even though the anti-inflammatory effects of antidepressants are yet to be evaluated fully [197]. Moreover, the immune system could contribute to BD pathology through the regulation of the hypothalamic-pituitary-adrenal (HPA) axis [177]. Proinflammatory cytokines increase HPA axis activity, resulting in increased systemic cortisol levels [198].

\section{Calcium Signaling Pathways}

One hypothesis for $\mathrm{BD}$ states that mtDNA mutations or mitochondrial RNA deletions lead to impaired mitochondrial regulation of calcium, causing BD symptoms $[54,199]$. Consistent with this hypothesis, calcium levels in peripheral cells of patients with BD have been found to be higher than normal [77,200-202]. A persistent increase in intracellular calcium can cause neurons to undergo degeneration and die [203]. Excess calcium in mitochondria induces mitochondrial permeability transition, after which the mitochondria swell and the outer mitochondrial membrane ruptures [204]. Furthermore, ROS production in mitochondria stimulates the uptake of $\mathrm{Ca}^{2+}$ and enhances membrane permeability, leading to cytochrome $c$ release and the initiation of apoptosis [203,205]. Mitochondrial permeability transition further hampers oxidative phosphorylation, inhibits citric acid cycle enzymes, reduces ATP synthesis, increases ROS generation, as well as increases the release of calcium and apoptogenic factors to the cytosol $[54,206,207]$. Increased calcium concentrations also result in an altered mitochondrial potential and the formation of superoxide ion radicals [204], thus contributing to a vicious cycle [74].

\section{Nutrients, Vitamins, and Micronutrients in BD}

Consumption of nutrients are beneficial to brain health and its functioning [208]. Diet can affect a range of processes that are altered in $\mathrm{BD}$, such as monoaminergic activity, 
mitochondrial activity, inflammation, OS, and neuroprogression [209-211]. Oxidants may be crucial to psychiatric disorders as they are linked to membrane-related pathology in the central nervous system [212,213]. Certain oxidants can cause adverse increases in other metabolites, which can lead to specific psychiatric symptoms [73]. As previously noted, BD is characterized by lipid peroxidation and changes in antioxidant enzymes [214]. Consequently, antioxidant compounds may improve symptoms and may be explored as an adjunctive therapy. For instance, minocycline, an antibiotic, seems to have neuroprotective effects through its antioxidant activity, a mechanism that is also applicable to the pathophysiology and treatment of BD $[215,216]$. Poor nutrition is often associated with OS and inflammation, which can impact the immune system [217]. Early studies suggest that anti-inflammatory agents are likely to be beneficial for patients with BD exhibiting immune dysregulation [15].

\subsection{Vitamin D}

A study of 118 BD patients found a vitamin D deficiency rate $4.7 \times$ greater than that in the general population [218]. In a cross-sectional case-control study, Naifar et al. measured 25-hydroxy vitamin $\mathrm{D}$ in the plasma of patients with acute decompensation of $\mathrm{BD}$ relative to healthy controls [219]. In contrast to the prior study, their analysis discovered significantly higher levels of 25-hydroxy vitamin $\mathrm{D}$ in the $\mathrm{BD}$ patients compared with the healthy controls [219]. The study revealed that an increase in 25-hydroxy vitamin D production is correlated with acute decompensation of BD. Vitamin D supplementation correlates with a decline in manic and depressive symptoms, but further studies on the efficacy of specific doses are needed to corroborate these data [220-222]. Vitamin D has also been shown to exhibit anti-inflammatory effects [217].

\subsection{Folic Acid}

Folic acid and folates are considered useful for treating depressive symptoms [223] due to their role in neurotransmitter synthesis and DNA methylation [224]. As reported in multiple studies, individuals who are depressed have lower concentrations of plasma and erythrocyte folate compared with both healthy people and people with other psychiatric disorders [225]. Reduced levels of folate correlate with poor responsiveness to antidepressant medication [226]. One study examined adding $200 \mu \mathrm{g} / \mathrm{d}$ of folic acid to lithium treatment in $\mathrm{BD}$, with the authors ultimately suggesting that folic acid supplementation may be used during maintenance therapy [226]. Behzadi et al. reported positive outcomes from the inclusion of folic acid along with valproates in the treatment of mania [227]. Moreover, recent studies encompassing a group of $10 \mathrm{BD}-\mathrm{I}$ patients undergoing depression have shown the advantageous effects of augmenting standard treatment with levomefolic acid [228]. Intake of folic acid as levomefolic acid may be more effective because levomefolic acid is more bioavailable [228].

\subsection{Magnesium and Copper}

Several reports have identified variations in the blood magnesium concentration of patients with BD [229]. One study highlighted significantly increased serum magnesium concentrations in patients with BD during mania, hypomania, and depression. However, during remission, serum magnesium returned to normal levels and did not differ from the levels in healthy controls [229]. Another study measured magnesium concentration in $129 \mathrm{BD}$ patients (23 exhibiting mania, 58 exhibiting depression, and 48 in remission) along with 50 healthy controls [229]. It found that the BD patients undergoing a depressive, manic, or hypomanic episode had significantly higher serum magnesium concentrations compared with the healthy controls [229]. The serum magnesium levels of the patients in remission were unaltered compared with those of the controls. These results suggest that serum magnesium may be used as a potential marker of the pathophysiological alterations accompanying acute $\mathrm{BD}$ [229]. In addition, several reports have noted altered serum copper levels in patients with BD [230]. A study of 133 BD patients (23 exhibiting 
mania/hypomania, 61 exhibiting depression, and 49 in remission) showed significantly increased levels of serum copper among patients in stage I compared with patients in advanced stages of the disorder [230].

\subsection{PUFAs}

Omega-3 PUFAs, such as eicosapentaenoic acid and docosahexaenoic acid (DHA), are critical to the development and activities of the brain, including neuronal migration, maturation, formation of synapses, neuronal plasticity, and synaptic transmission [226]. Alterations in PUFA levels have been suggested to be present in BD [231,232]. An analysis of six studies including a total of 118 BD-I patients and 147 healthy controls showed deficits in erythrocyte DHA and decreased eicosapentaenoic acid in the BD-I patients [232]. Omega-3 PUFAs have been suggested as possible therapeutic supplements for a variety of illnesses, such as cancer, diabetes, arteriosclerosis, hypertension, arthritis, psychiatric disorders, dementia, and autoimmune diseases [233]. More specifically, study results for the use of omega-3 PUFAs in BD have been encouraging [234-237]. The increase in BDNF levels caused by omega-3 PUFAs has been proposed to account for how omega-3 PUFAs may enhance the outcomes of BD [235]. In addition, recent research indicates that anti-inflammatory medication might contribute to mood disorder treatment [21]. Omega-3 PUFAs, naturally occurring anti-inflammatory agents, are found to be well-tolerated [208,238,239]. In a randomized controlled trial (RCT), omega- 3 fatty acids displayed a significant antidepressant effect in subjects with high inflammatory marker levels [240].

Multiple epidemiological and experimental studies have considered the association between dietary intake/supplementation of PUFAs and incidence or severity of depression [241]. Some research studies have also proposed that increased dietary PUFA consumption in patients with BD is beneficial [242]. Daily administration of 1 to $2 \mathrm{~g}$ of eicosapentaenoic acid has been found to reduce depressive symptoms, including those in patients with BD-I [243]. Another study examined the effectiveness of prophylactic administration of omega-3 PUFAs in BD: Eighty patients with BD were randomized such that 40 received placebo and the other 40 received $1 \mathrm{~g}$ of eicosapentaenoic acid as well as $1 \mathrm{~g}$ of DHA as adjunctive therapy for 52 weeks [244]. The study determined that omega-3 PUFA administration had a prophylactic effect in the patients. A double-blind randomized trial assessed daily DHA supplementation at $1250 \mathrm{mg}$ versus placebo for 12 weeks in 31 BD patients who were euthymic and 15 healthy controls [245]. In contrast to the above-mentioned results, the trial found improved cognitive function based on performance in emotion inhibition only in healthy controls who received DHA for 12 weeks. This finding suggests that DHA supplementation may be effective in increasing cognitive performance, but further research on this topic is required [245].

\section{Anti-Inflammatory Agents}

In addition to omega-3 fatty acids and vitamin $\mathrm{D}$, other nutrients with reported antiinflammatory and antioxidant effects include vitamin A, vitamin C, and phytochemicals such as polyphenols and carotenoids [246-248]. Vitamin C is considered an antioxidant because it quenches free radicals while being oxidized into dehydroascorbic acid [248]. Moreover, it has been shown to act on neutrophils to induce phagocytosis, ROS generation, and migration to the infection site [249,250]. Omega-3 fatty acids; vitamins A, C, and D; polyphenols; carotenoids; and other anti-inflammatory compounds might contribute to the homeostatic regulation of OS and inflammation, both under normal conditions and during infection. Clinical trials involving patients with BD have demonstrated encouraging results for a diverse group of anti-inflammatory agents [251]. When aspirin, celecoxib, infliximab, $\mathrm{N}$-acetylcysteine (NAC), omega-3 fatty acids, and pioglitazone were administered as adjuvant therapy, they were found to be effective in reducing BD-related depression [251]. Evidence has particularly supported the use of NAC as an adjuvant therapeutic agent for BD-related depression [252]. In an RCT involving 75 patients with BD, adjunctively administered NAC significantly reduced depression severity after 24 weeks compared to 
conventional treatment alone [253]. Of note, valproate also exhibited anti-inflammatory effects both systemically and in the CNS in encephalomyelitis rat models [254]. Moreover, valproic acid was found to reduce proinflammatory cytokine production in controls [255].

\section{Lithium Therapy}

Lithium, the first-line drug treatment for BD, both for bipolar depression [256-261] and for mixed episodes [262-274] has numerous neuroprotective, neurotrophic, and neuroplastic effects [275-278]. In addition to being the mood stabilizer conventionally used in ameliorating the pathophysiology of BD, lithium has some antidepressant activity [279-282]. The therapeutic effects of lithium have been hypothesized to be partially linked to its antioxidant capabilities. One study examined 29 BD patients in a depressive episode who were treated with lithium for 6 weeks as well as 28 controls [145]. Plasma TBARS levels as well as SOD, CAT, and GPX activities were measured at baseline and 6 weeks in both groups [145]. Lithium administration only caused a decrease in TBARS and SOD levels; this was most evident in BD-II $[106,145]$. TBARS levels were significantly lower after 6 weeks in patients who responded to lithium compared with those who did not $[95,145]$.

A similar study showed significantly lower TBARS and SOD:CAT levels in BD patients [283] who were administered lithium but not in healthy people given lithium $[155,284]$. Short-term lithium treatment has been shown to lower SOD:CAT and TBARS levels in patients with BD who were experiencing mania as well [95]. These outcomes were corroborated by a follow-up study showing a reduction in SOD and TBARS levels in patients with BD after 6 weeks of lithium therapy [285]. The study also found that lithium responders exhibited significantly lower TBARS levels compared with nonresponders [106].

Taken together, these findings support the role of OS in the pathophysiology of BD, in addition to the role of the antioxidant activity of lithium in providing effective clinical intervention [286-289]. Moreover, lithium reduces proapoptotic activities and increases the level of neuroprotective proteins, including Bcl-2 [81,290,291]. These mechanisms may contribute to the neuroprotective action of the drug. Lithium reportedly exhibits anti-inflammatory activity through the inhibition of IL-1B, TNF- $\alpha$, and cyclooxygenase- 2 synthesis and stimulation of IL-2 and IL-10 production [16,292-294]. There have also been reports on lithium's proinflammatory effects, such as the enhancement of IL-4, IL-6, and other inflammatory cytokine synthesis $[208,295,296]$. Through its anti-inflammatory effects, lithium was found to decrease proinflammatory cytokine levels and alleviate manic behavior in a mouse model of mania [297]. Two recent preclinical studies reported on the neuroprotective effects of lithium. In a study focusing on rat glia, lithium pretreatment reduced TNF- $\alpha$, IL- $1 \beta$, $\mathrm{NO}$, and prostaglandin $\mathrm{E}_{2}$ secretion in response to lipopolysaccharide-induced inflammation [298,299]. In another study using a rat model of intracerebral hemorrhage, lithium prevented perihematomal cell death and reduced COX-2 expression and reactive microglia number [298,300]. In addition to regulating apoptosis, lithium is known to protect against excitotoxicity [301,302] as well as to increase BDNF and intracellular calcium levels [145]. It causes an increase in neuroplasticity, which mitigates the reduction in gray and white matter observed in BD [301] and may ameliorate the visuospatial asymmetry produced by BD [303]. Lithium therapy has demonstrated frontal cortex enhanced electron transport chain complexes I, II, and III activity in the postmortem brains of patients with BD [304]. In addition, de Sousa et al. observed the ability of lithium to improve the activity of electron transport chain complex I in the leukocytes of patients with BD to an extent dependent on the plasma lithium level [305]. By affecting a range of biological processes, lithium has proven to be a potent treatment for BD [306-312].

\section{Antipsychotic Agents}

Antipsychotic agents are effective in managing the symptoms of mania by blocking DA $\mathrm{D}_{2}$ receptors $[91,313]$. Therefore, people with BD-I who undergo manic episodes are more likely to be prescribed antipsychotic agents [314,315]. A recent meta-analysis showed the efficacy of typical and atypical antipsychotic agents in the treatment of mania, suggesting 
that disrupted signaling of DA may contribute to the presentation of manic symptoms in patients with BD [316,317]. Atypical antipsychotic agents, including olanzapine, clozapine, risperidone, quetiapine, aripiprazole, cariprazine, and ziprasidone, are classified as first-line medications for psychotic depression [314,318-321]. They are the preferred antipsychotic agents for long-term maintenance therapy [318-321].

\subsection{Clozapine}

Some patients with BD, including those who respond poorly to mood stabilizers and typical antipsychotic agents or who exhibit rapid cycling, may benefit from the use of clozapine [314,322]. Especially among older adults, clozapine may be beneficial in the treatment of BD and psychotic disorders [323]. Several research studies have shown that the efficacy of clozapine is increased during the manic phase of BD, as depicted in a study where patients with $\mathrm{BD}$ who were in a manic/mixed state responded better than did those who were in a depressed state [314]. The effectiveness of clozapine in the maintenance treatment of BD has been described in four open-label studies, of which three with a prospective study design specifically explored its effectiveness in mania [314].

In one study assessing the clinical benefit and adverse effects of clozapine, 100 and 102 patients with BD were administered clozapine and other antipsychotic agents, respectively [324]. Clozapine was found to have equivalent efficacy relative to the other antipsychotic agents for mania, and it outperformed them for treatment-resistant BD (TRBD) [324]. Fifteen clinical trials with 1044 patients in total were designed to evaluate the use of clozapine for TRBD [325]. Although the existing data are limited, they support the use of clozapine as a potent and safe treatment for TRBD [325]. In a mirror image study, 62 patients with BD who were in remission initially received clozapine treatment; of those patients, 25 were transferred to another antipsychotic treatment after a change in drug reimbursement, whereas 37 continued receiving clozapine [326]. The study indicated that a shift from clozapine to another antipsychotic agent might increase the likelihood of recurrence for BD patients in remission [326]. In addition, a case study found that $3 \mathrm{BD}$ patients who had suicidal ideation benefited from the addition of clozapine to their treatment regimen, thereby suggesting that clozapine is a promising and safe medication for suicidality [327]. However, treatment with clozapine poses detrimental side effects, including a substantial risk of agranulocytosis, which could lead to death [314].

\subsection{Olanzapine}

Olanzapine may be a competent maintenance drug treatment due to its antimanic and antidepressant effects [314]. In a group of patients with BD who were given olanzapine, a significantly better mean improvement in mania ratings and a significantly higher proportion of patients who attained remission were observed [314]. Furthermore, the results of an 8 -week double-blind study of BD-I patients with depression administered placebo $(n=355)$ or olanzapine $(5-20 \mathrm{mg} / \mathrm{d} ; n=351)$ revealed the efficacy of olanzapine as a therapeutic agent for mixed depression in BD-I [328].

\subsection{Risperidone}

Systematic investigations have demonstrated the efficacy and safety of using risperidone in the treatment of acute mania, either as an adjuvant therapy to lithium or valproate or as a stand-alone treatment [314]. In a 6-month multicenter open trial, risperidone proved to be safe and effective in the long term as an add-on treatment for TRBD, and it did not aggravate manic symptoms [314]. The study did reveal some adverse effects of risperidone, which were largely moderate and included weight gain [314]. A retrospective cohort study conducted with 469 BD-I patients who were given long-acting injections of risperidone for 1 year, in addition to concomitant BD medications, found that risperidone long-acting injections may decrease the severity of BD-I [157]. An exploratory analysis of 162 BD patients who had frequent relapses noted improvement in clinical status, depressive symptoms, and manic symptoms after add-on risperidone long-acting injection treatment [329]. 
Several other studies have investigated the efficacy of risperidone in pediatric patients with BD. One retrospective study observed pediatric patient charts over 18 months in an outpatient clinic for mood disorders [330]. Data obtained for BD patients with aggression who were prescribed risperidone revealed that mood stabilizers alone were ineffective in managing symptoms. Throughout the follow-up period, aggression and manic symptoms decreased in all patients [330]. Overall, the study established that the addition of risperidone may improve mania and aggression in pediatric BD patients who have inadequate responses to mood stabilizers alone [330]. A similar open study of 22 pediatric BD patients in a manic, hypomanic, or mixed state reported that 8 weeks of risperidone monotherapy $(1.25 \pm 1.5 \mathrm{mg} / \mathrm{d})$ was associated with significantly improved symptoms [331].

\subsection{Cariprazine}

Cariprazine, which has been authorized for use in the treatment of mania accompanying $\mathrm{BD}$, is a partial $\mathrm{D}_{2} / \mathrm{D}_{3}$ receptor agonist [332-338]. It appears to be a safe and effective medication for acute mania and mixed episodes in BD [339-342]. Some research data have indicated that both low and high doses of cariprazine are effective and well tolerated as a drug treatment for mania, depression, and psychosis [343-345]. RCTs of BD-I patients in manic and mixed episodes found the greatest treatment benefit when cariprazine was provided in the range of 3 to $12 \mathrm{mg}$ [346,347]. Placebo-controlled studies of bipolar depression have indicated that 1.5 to $3 \mathrm{mg} / \mathrm{d}$ of cariprazine monotherapy is a competent treatment for acute depression in BD [346].

Durgam et al. conducted a phase II trial on 239 research participants assigned either to a placebo group or to a group receiving flexible doses of cariprazine [348]. Of the participants, $66.1 \%$ were administered a final dose of $12 \mathrm{mg} / \mathrm{d}, 16.9 \%$ were administered $9 \mathrm{mg} / \mathrm{d}, 12.7 \%$ were administered $6 \mathrm{mg} / \mathrm{d}$, and $4.2 \%$ were administered $3 \mathrm{mg} / \mathrm{d}$. Across the cariprazine group, the average dose was $8.8 \mathrm{mg} / \mathrm{d}$ [348]. Overall, the group administered cariprazine exhibited significantly greater gains in the Young Mania Rating Scale compared with the group that received placebo [348]. Another double-blind placebo-controlled trial randomly allocated placebo $(n=158), 1.5 \mathrm{mg} / \mathrm{d}$ of cariprazine $(n=157)$, and $3.0 \mathrm{mg} / \mathrm{d}$ of cariprazine $(n=165)$ in adult BD-I patients who were in a depressive episode [349]. Both cariprazine doses were safe, well tolerated, and effective in decreasing depressive symptoms [349]. Although a singular dosage recommendation has not been standardized for cariprazine yet, the results of these studies indicate its efficacy in certain cases of BD [346-349].

\subsection{Quetiapine}

The antipsychotic actions of quetiapine are likely derived from its antagonistic activity against $\mathrm{DA} \mathrm{D}_{2}$ receptors and serotonin 5-hydroxytryptamine 2 receptors [350]. Quetiapine is an atypical antipsychotic agent that is administered orally [351,352]. On occasion, it is recommended for the treatment of $\mathrm{BD}$, although some studies have suggested that it is more successful specifically in alleviating the symptoms of anxiety and depression accompanying BD [351-354]. Five double-blind RCTs evaluated the tolerability and effectiveness of quetiapine over 8 weeks in BD patients who were undergoing a major depressive episode [350]. Quetiapine monotherapy at $300 \mathrm{mg} / \mathrm{d}$, that at $600 \mathrm{mg} / \mathrm{d}$, and extended-release quetiapine monotherapy at $300 \mathrm{mg} / \mathrm{d}$ caused a significantly greater improvement in MontgomeryAsberg Depression Rating Scale scores compared with placebo [350]. Another RCT over 104 weeks found that quetiapine used as maintenance drug therapy was more effective than lithium or placebo in preventing relapse [350]. However, the study only included patients who previously responded to quetiapine during the acute phase of BD [350]. Thus, a bias for quetiapine over lithium in the study sample may have already been present. In the patients with bipolar depression, the adverse effects of quetiapine at $300 \mathrm{mg} / \mathrm{d}$, quetiapine at $600 \mathrm{mg} / \mathrm{d}$, and extended-release quetiapine at $300 \mathrm{mg} / \mathrm{d}$ were mild or moderate; in general, all three quetiapine doses were well tolerated [350]. 


\section{Role of Therapies}

A number of therapies have demonstrated successful outcomes in $\mathrm{BD}$, including psychotherapies (CBT and ImCT), phototherapy (BLT), and ECT.

\section{1. $C B T$}

CBT has classically been used to treat depression and increase self-esteem through cognitive restructuring [355-357]. In addition to being used to treat unipolar depression, it has also been adapted to treat BD [358-363]. Studies on the use of CBT for BD have suggested the use of CBT as an add-on treatment to pharmacotherapy to prevent depressive symptoms and relapse $[357,364]$. Chiang et al. systematically analyzed the findings of 19 RCTs in which CBT was used as an adjuvant to pharmacotherapy [357]. Their analysis supported the adjunctive use of CBT in BD because of its clinical benefit both after treatment and during follow-up [357]. Moreover, a case study on 3 BD-II patients showed that the rate of $\mathrm{BD}$ recurrence could be decreased by the use of $\mathrm{CBT}$ as an adjuvant to medication [365]. The group format of CBT is also a potentially useful intervention for BD, as indicated by a study in which 41 patients with BD received 14 sessions of group CBT along with medication [366]. In the study, group CBT was found to improve depressive symptoms [366]. Likewise, another study of patients with BD reported that the group format of CBT was effective in decreasing fluctuations in mood state [356].

\subsection{BLT}

BLT, also known as phototherapy, uses glare therapy in the treatment of the symptoms of depression [367-374]. Some research studies have reported that BLT was successful as an adjunctive therapy for BD [375-380]. Tseng et al. demonstrated significant antidepressant activity with BLT [381]. Additional lines of evidence from RCTs have shown that BLT may reduce the symptoms of depression among the general population [382-388]. One benefit of BLT over antidepressants is that its risk of causing a switch to mania is lower $(2.3 \%$ vs. $15-40 \%)$ [389]. Similarly, the effects of light therapy were analyzed in four trials on a total sample of 190 patients with bipolar depression, 94 of whom received the intervention [390]. The meta-analysis revealed a risk ratio of response to light therapy of 1.78 (95\% confidence interval, 1.24-2.56) in patients with BD [390]. Another trial of 63 research participants investigated the effects of $1 \mathrm{~h}$ of light therapy daily for 2 weeks [391]. Thirty-three participants received BLT, whereas 30 received dim red light therapy. The outcomes of the study indicate that BLT may be an effective and safe adjuvant for acute depression in BD [391].

\section{3. $\operatorname{Im} C T$}

An imagery-focused intervention addressing mood and anxiety in BD found that it helped reduce clinical symptoms [392,393]. In addition, patients with BD accepted and were highly satisfied with the intervention [392,393]. Eleven patients with BD were administered a combination of ImCT and standard care in one study, where their moods were monitored 6 months pre- and posttreatment [393]. In addition, their anxiety was measured for 1 month from the initiation of treatment. The study provided promising results, suggesting that the addition of ImCT to standard care could alleviate the depressive and anxious symptoms of $\mathrm{BD}$ in a manner that is satisfactory to patients [393].

\subsection{ECT}

ECT is a fast-acting and potent method for stimulating the brain [394,395]. It is often used in major depression, but it can also be effective in TRBD [396-398]. For instance, a study of 344 patients with BD found that ECT was safe and effective in all stages of severe and medication-resistant BD [399]. The quick antidepressant action of ECT likely contributes to long-term prevention of suicide in affective illnesses, such as BD and major depressive disorder $[400,401]$. An investigation of 487 patients with BD or unipolar depression from 2000 to 2013 reported that those who underwent ECT had a 19.7\% lower 
probability of suicide compared with those who did not [401]. The therapeutic action of ECT for BD may be due to its influence on OS [396]. In one study, 28 TRBD patients and 49 controls received ECT, and several OS parameters were measured (SOD, GPX, CAT, and MDA) [396]. The outcomes suggested that a decline in lipid peroxidation levels contributed to the efficiency of ECT [396]. MDA levels were shown to decline exclusively in ECT responders, which points to the possible role of MDA reduction in the efficiency of ECT [396]. This suggests that OS is associated with BD severity and the response to ECT [396].

\section{Conclusions}

$\mathrm{BD}$ is becoming increasingly understood as a condition of aberrant neuroplasticity. Multiple factors, such as OS, imbalance of neurotransmitters, and genetics, are associated with the pathophysiology of BD. OS, caused by an imbalance between oxidant and antioxidant enzymes, may lead to cell damage. Decreased antioxidants and greater production of oxidizing agents lead to OS, causing alterations in proteins, carbohydrates, lipids, and DNA. In addition, reactive species act on mitochondria to eventually lead to increased concentrations of ROS/reactive nitrogen species, further oxidizing mitochondrial lipids, proteins, and DNA. In this regard, BD is associated with lipid peroxidation and DNA damage. Consistent with this observation, TBARS levels, which act as a lipid peroxidation marker, tend to be increased in patients with BD. Moreover, patients with BD have reduced $\mathrm{BDNF}$ levels, along with altered $\mathrm{Ca}^{2+}$ homeostasis and increased peripheral $\mathrm{Ca}^{2+}$ levels. Studies of both CNS-related and systemic cytokine changes in patients with BD have indicated that the neuroimmune system plays an important role in BD pathophysiology. Therefore, nutraceuticals may have a role in the adjuvant treatment of BD.

An accumulating body of evidence suggests that the therapeutic use of antioxidants in $\mathrm{BD}$ is beneficial in the treatment of depression associated with BD. Supplements that have been proposed to have therapeutic value in BD include vitamin D, omega-3 PUFAs, and folic acid. In addition to omega-3 fatty acids and vitamin $\mathrm{D}$, other nutrients such as vitamin A, vitamin C, polyphenols, carotenoids, and other anti-inflammatory compounds might contribute to the homeostatic regulation of OS and inflammation. To date, lithium is the leading mood stabilizer used to ameliorate the pathophysiology of BD because of its effects on neuroplasticity. Oral antipsychotic agents, such as clozapine, olanzapine, risperidone, cariprazine, and quetiapine, are regarded as the first-line drug treatments for psychotic depression, and they are especially recommended for maintenance therapy. In addition, CBT, BLT, ImCT, and ECT have all been proven as effective adjuvant therapies for the treatment of BD.

Author Contributions: S.M. (Sahithi Madireddy) and S.M. (Samskruthi Madireddy) have contributed equally. All authors have read and agreed to the published version of the manuscript.

Funding: This research received no external funding.

Conflicts of Interest: The authors declare no conflict of interest.

\section{References}

1. Husain, S.F.; Tang, T.-B.; Tam, W.W.; Tran, B.X.; Ho, C.S.; Ho, R.C. Cortical haemodynamic response during the verbal fluency task in patients with bipolar disorder and borderline personality disorder: A preliminary functional near-Infrared spectroscopy study. BMC Psychiatry 2021, 21, 201. [CrossRef] [PubMed]

2. Muller, J.K.; Leweke, F.M. Bipolar disorder: Clinical overview. Med. Mon. Pharm. 2016, 39, 363-369.

3. McIntyre, R.; Berk, M.; Brietzke, E.; Goldstein, B.I.; López-Jaramillo, C.; Kessing, L.V.; Malhi, G.S.; Nierenberg, A.A.; Rosenblat, J.D.; Majeed, A.; et al. Bipolar disorders. Lancet 2020, 396, 1841-1856. [CrossRef]

4. Moreira, F.P.; Cardoso, T.C.; Mondin, T.C.; Wiener, C.D.; de Mattos Souza, L.D.; Oses, J.P.; Jansen, K.; da Silva, R.A. Serum level of nerve growth factor is a potential biomarker of conversion to bipolar disorder in women with major depressive disorder. Psychiatry Clin. Neurosci. 2019, 73, 590-593. [CrossRef] [PubMed]

5. Milev, R. The role of electroconvulsive therapy in the treatment of bipolar disorder. In The Treatment of Bipolar Disorder: Integrative Clinical Strategies and Future Directions; Carvalho, A.F., Vieta, E., Eds.; Oxford University Press: Oxford, UK, 2017 ; pp. 408-422.

6. Cotrena, C.; Branco, L.D.; Kochhann, R.; Shansis, F.M.; Fonseca, R.P. Quality of life, functioning and cognition in bipolar disorder and major depression: A latent profile analysis. Psychiatry Res. 2016, 241, 289-296. [CrossRef] [PubMed] 
7. Smeland, O.B.; Bahrami, S.; Frei, O.; Shadrin, A.; O'Connell, K.; Savage, J.; Watanabe, K.; Krull, F.; Bettella, F.; Steen, N.E.; et al. Genome-wide analysis reveals extensive genetic overlap between schizophrenia, bipolar disorder, and intelligence. Mol. Psychiatry 2020, 25, 844-853. [CrossRef]

8. Correll, C.U.; Solmi, M.; Veronese, N.; Bortolato, B.; Rosson, S.; Santonastaso, P.; Thapa-Chhetri, N.; Fornaro, M.; Gallicchio, D.; Collantoni, E.; et al. Prevalence, incidence and mortality from cardiovascular disease in patients with pooled and specific severe mental illness: A large-scale meta-analysis of 3,211,768 patients and 113,383,368 controls. World Psychiatry 2017, 16, 163-180. [CrossRef]

9. Kim, H.K.; Andreazza, A.C.; Yeung, P.Y.; Isaacs-Trepanier, C.; Young, L.T. Oxidation and nitration in dopaminergic areas of the prefrontal cortex from patients with bipolar disorder and schizophrenia. J. Psychiatry Neurosci. 2014, 39, 276-285. [CrossRef]

10. Islam, T. Oxidative stress and mitochondrial dysfunction-linked neurodegenerative disorders. Neurol. Res. 2017, 39, 73-82. [CrossRef]

11. Kausar, S.; Wang, F.; Cui, H. The role of mitochondria in reactive oxygen species generation and its implications for neurodegenerative diseases. Cells 2018, 7, 274. [CrossRef]

12. Naaldijk, Y.M.; Bittencourt, M.C.; Sack, U.; Ulrich, H. Kinins and microglial responses in bipolar disorder: A neuroinflammation hypothesis. Biol. Chem. 2016, 397, 283-296. [CrossRef] [PubMed]

13. Rege, S.; Hodgkinson, S.J. Immune dysregulation and autoimmunity in bipolar disorder: Synthesis of the evidence and its clinical application. Aust. N. Z. J. Psychiatry 2013, 47, 1136-1151. [CrossRef] [PubMed]

14. Reus, G.Z.; Fries, G.R.; Stertz, L.; Badawy, M.; Passos, I.C.; Barichello, T.; Kapczinski, F.; Quevedo, J. The role of inflammation and microglial activation in the pathophysiology of psychiatric disorders. Neuroscience 2015, 300, 141-154. [CrossRef]

15. Rosenblat, J.D. Targeting the immune system in the treatment of bipolar disorder. Psychopharmacology 2019, 236, 2909-2921. [CrossRef]

16. Rosenblat, J.D.; McIntyre, R.S. Bipolar disorder and inflammation. Psychiatr. Clin. N. Am. 2016, 39, 125-137. [CrossRef] [PubMed]

17. Rosenblat, J.D.; Ron Kakar, R.; Berk, M.; Kessing, L.V.; Vinberg, M.; Baune, B.T.; Mansur, R.B.; Brietzke, E.; Goldstein, B.I.; McIntyre, R.S. Anti-inflammatory agents in the treatment of bipolar depression: A systematic review and meta-analysis. Bipolar. Disord. 2016, 18, 89-101. [CrossRef]

18. Young, A.H.; Juruena, M.F. The neurobiology of bipolar disorder. Curr. Top. Behav. Neurosci. 2021, 48, 1-20.

19. Gao, W.; Cui, D.; Jiao, Q.; Su, L.; Yang, R.; Lu, G. Brain structural alterations in pediatric bipolar disorder patients with and without psychotic symptoms. J. Affect. Disord. 2021, 286, 87-93. [CrossRef]

20. Knorr, U.; Simonsen, A.H.; Roos, P.; Weimann, A.; Henriksen, T.; Christensen, E.-M.; Vinberg, M.; Mikkelsen, R.L.; Kirkegaard, T.; Jensen, R.N.; et al. Cerebrospinal fluid oxidative stress metabolites in patients with bipolar disorder and healthy controls, a longitudinal case-control study. Transl. Psychiatry 2019, 9, 325. [CrossRef]

21. Chandrasekaran, V.; Brennan-Olsen, S.L.; Stuart, A.L.; Pasco, J.A.; Berk, M.; Hodge, J.M.; Williams, L.J. Bipolar disorder and bone health: A systematic review. J. Affect. Disord. 2019, 249, 262-269. [CrossRef]

22. Shen, S.-H.; Lee, S.-H. A case of lung cancer with brain metastasis following late-onset bipolar disorder. Behav. Neurol. 2021, 2021, 8880539. [CrossRef] [PubMed]

23. Rantala, M.J.; Luoto, S.; Borráz-León, J.I.; Krams, I. Bipolar disorder: An evolutionary psychoneuroimmunological approach. Neurosci. Biobehav. Rev. 2021, 122, 28-37. [CrossRef] [PubMed]

24. Lucidi, L.; Pettorruso, M.; Vellante, F.; Di Carlo, F.; Ceci, F.; Santovito, M.C.; Di Muzio, I.; Fornaro, M.; Ventriglio, A.; Tomasetti, C.; et al. Gut microbiota and bipolar disorder: An overview on a novel biomarker for diagnosis and treatment. Int. J. Mol. Sci. 2021, 22, 3723. [CrossRef] [PubMed]

25. Morris, G.; Walder, K.R.; Berk, M.; Marx, W.; Walker, A.J.; Maes, M.; Puri, B.K. The interplay between oxidative stress and bioenergetic failure in neuropsychiatric illnesses: Can we explain it and can we treat it? Mol. Biol. Rep. 2020, 47, 5587-5620. [CrossRef]

26. Vieta, E.; Berk, M.; Schulze, T.G.; Carvalho, A.F.; Suppes, T.; Calabrese, J.R.; Gao, K.; Miskowiak, K.W.; Grande, I. Bipolar disorders Nat. Rev. Dis. Prim. 2018, 4, 18008. [CrossRef] [PubMed]

27. Gordovez, F.J.A.; McMahon, F.J. The genetics of bipolar disorder. Mol. Psychiatry 2020, 25, 544-559. [CrossRef]

28. Bonnín, C.D.M.; Reinares, M.; Martínez-Arán, A.; Jiménez, E.; Sánchez-Moreno, J.; Solé, B.; Montejo, L.; Vieta, E. Improving functioning, quality of life, and well-being in patients with bipolar disorder. Int. J. Neuropsychopharmacol. 2019, 22, 467-477. [CrossRef]

29. Anderson, G.; Maes, M. Bipolar disorder: Role of immune-inflammatory cytokines, oxidative and nitrosative stress and tryptophan catabolites. Curr. Psychiatry Rep. 2015, 17, 8. [CrossRef]

30. O'Rourke, N.; Sixsmith, A.; Kirshner, G.; Osher, Y. Perceived cognitive failures and quality of life for older adults with bipolar disorder. J. Affect. Disord. 2021, 287, 433-440. [CrossRef]

31. Kessing, L.V.; Andersen, P.K. Evidence for clinical progression of unipolar and bipolar disorders. Acta Psychiatr. Scand. 2017, 135, 51-64. [CrossRef]

32. Cardoso, T.; Bauer, I.E.; Meyer, T.D.; Kapczinski, F.; Soares, J.C. Neuroprogression and cognitive functioning in bipolar disorder: A systematic review. Curr. Psychiatry Rep. 2015, 17, 75. [CrossRef]

33. Cyrino, L.A.R.; Delwing-de Lima, D.; Ullmann, O.M.; Maia, T.P. Concepts of neuroinflammation and their relationship with impaired mitochondrial functions in bipolar disorder. Front. Behav. Neurosci. 2021, 15. [CrossRef]

34. Liu, X.; Ma, X.; Wang, W.; Zhang, J.; Sun, X.; Luo, X.; Zhang, Y. The functional impairment of different subtypes and occupational states in euthymic patients with bipolar disorder. BMC Psychiatry 2021, 21, 240. [CrossRef] 
35. Grande, I.; Berk, M.; Birmaher, B.; Vieta, E. Bipolar disorder. Lancet 2016, 387, 1561-1572. [CrossRef]

36. Kurtz, M.; Mohring, P.; Förster, K.; Bauer, M.; Kanske, P. Deficits in explicit emotion regulation in bipolar disorder: A systematic review. Int. J. Bipolar Disord. 2021, 9, 1-23.

37. Clemente, A.S.; Diniz, B.S.; Nicolato, R.; Kapczinski, F.P.; Soares, J.C.; Firmo, J.O.; Castro-Costa, E. Bipolar disorder prevalence: A systematic review and meta-analysis of the literature. Braz. J. Psychiatry 2015, 37, 155-161. [CrossRef]

38. Phillips, C. Physical activity modulates common neuroplasticity substrates in major depressive and bipolar disorder. Neural. Plast. 2017, 2017, 7014146. [CrossRef]

39. Gandhi, A.B.; Kaleem, I.; Alexander, J.; Hisbulla, M.; Kannichamy, V.; Antony, I.; Mishra, V.; Banerjee, A.; Khan, S. Neuroplasticity improves bipolar disorder: A review. Cureus 2020, 12, e11241. [CrossRef] [PubMed]

40. Dell'Osso, B.; Dobrea, C.; Cremaschi, L.; Buoli, M.; Miller, S.; Ketter, T.A.; Altamura, A.C. Italian bipolar II vs I patients have better individual functioning, in spite of overall similar illness severity. CNS Spectr. 2017, 22, 325-332. [CrossRef] [PubMed]

41. Coryell, W.; Kriener, A.; Butcher, B.; Nurnberger, J.; McMahon, F.; Berrettini, W.; Fiedorowicz, J. Risk factors for suicide in bipolar I disorder in two prospectively studied cohorts. J. Affect. Disord. 2016, 190, 1-5. [CrossRef] [PubMed]

42. Tondo, L.; Vázquez, G.H.; Baldessarini, R.J. Prevention of suicidal behavior in bipolar disorder. Bipolar Disord. 2021, $23,14-23$. [CrossRef]

43. Wah, A.; Hodge, S.; Jones, S.H.; Perez Algorta, G. A qualitative exploration of how people with bipolar disorder consider risk-taking in everyday decisions. Behav. Cogn. Psychother. 2021, 49, 314-327. [CrossRef]

44. Diniz, B.S.; Teixeira, A.L.; Cao, F.; Gildengers, A.; Soares, J.C.; Butters, M.A.; Reynolds, C.F. History of bipolar disorder and the risk of dementia: A systematic review and meta-analysis. Am. J. Geriatr. Psychiatry 2017, 25, 357-362. [CrossRef] [PubMed]

45. Merikangas, K.R.; Akiskal, H.S.; Angst, J.; Greenberg, P.E.; Hirschfeld, R.M.; Petukhova, M.; Kessler, R.C. Lifetime and 12-month prevalence of bipolar spectrum disorder in the national comorbidity survey replication. Arch. Gen. Psychiatry 2007, 64, 543-552. [CrossRef] [PubMed]

46. Fiedorowicz, J.G.; Palagummi, N.M.; Forman-Hoffman, V.L.; Miller, D.D.; Haynes, W.G. Elevated prevalence of obesity, metabolic syndrome, and cardiovascular risk factors in bipolar disorder. Ann. Clin. Psychiatry 2008, 20, 131-137. [CrossRef] [PubMed]

47. Schoepf, D.; Heun, R. Bipolar disorder and comorbidity: Increased prevalence and increased relevance of comorbidity for hospital-based mortality during a 12.5-year observation period in general hospital admissions. J. Affect. Disord. 2014, 169, 170-178. [CrossRef] [PubMed]

48. Hui Poon, S.; Sim, K.; Baldessarini, R.J. Pharmacological approaches for treatment-resistant bipolar disorder. Curr. Neuropharmacol. 2015, 13, 592-604. [CrossRef]

49. Gold, A.K.; Otto, M.W.; Deckersbach, T.; Sylvia, L.G.; Nierenberg, A.A.; Kinrys, G. Substance use comorbidity in bipolar disorder: A qualitative review of treatment strategies and outcomes. Am. J. Addict. 2018, 27, 188-201. [CrossRef]

50. Hansson, C.; Joas, E.; Pålsson, E.; Hawton, K.; Runeson, B.; Landén, M. Risk factors for suicide in bipolar disorder: A cohort study of 12850 patients. Acta Psychiatry Scand. 2018, 138, 456-463. [CrossRef]

51. Sagar, R.; Pattanayak, R.D. Potential biomarkers for bipolar disorder, Where do we stand? Indian J. Med. Res. 2017, 145, 7-16. [CrossRef]

52. Munkholm, K.; Vinberg, M.; Kessing, L.V. Peripheral blood brain-derived neurotrophic factor in bipolar disorder: A comprehensive systematic review and meta-analysis. Mol. Psychiatry 2016, 21, 216-228. [CrossRef]

53. Wang, S.; Zhang, Z.; Yao, L.; Ding, N.; Jiang, L.; Wu, Y. Bright light therapy in the treatment of patients with bipolar disorder: A systematic review and meta-analysis. PLoS ONE 2020, 15, e0232798. [CrossRef] [PubMed]

54. Sigitova, E.; Fišar, Z.; Hroudová, J.; Cikánková, T.; Raboch, J. Biological hypotheses and biomarkers of bipolar disorder. Psychiatry Clin. Neurosci. 2017, 71,77-103. [CrossRef] [PubMed]

55. Szepesi, Z.; Manouchehrian, O.; Bachiller, S.; Deierborg, T. Bidirectional microglia-neuron communication in health and disease. Front. Cell Neurosci. 2018, 12, 323. [CrossRef] [PubMed]

56. Leff-Gelman, P.; Mancilla-Herrera, I.; Flores-Ramos, M.; Cruz-Fuentes, C.; Reyes-Grajeda, J.P.; García-Cuétara, M.D.P.; BugnotPérez, M.D.; Pulido-Ascencio, D.E. The immune system and the role of inflammation in perinatal depression. Neurosci. Bull. 2016, 32, 398-420. [CrossRef] [PubMed]

57. Juruena, M.F.; Jelen, L.A.; Young, A.H.; Cleare, A.J. New pharmacological interventions in bipolar disorder. Curr. Top. Behav. Neurosci. 2021, 48, 303-324. [PubMed]

58. Fries, G.R.; Walss-Bass, C.; Bauer, M.E.; Teixeira, A.L. Revisiting inflammation in bipolar disorder. Pharmacol. Biochem. Behav. 2019, 177, 12-19. [CrossRef]

59. Miller, A.H.; Raison, C.L. The role of inflammation in depression, From evolutionary imperative to modern treatment target. Nat. Rev. Immunol. 2016, 16, 22-34. [CrossRef]

60. Setiawan, E.; Wilson, A.A.; Mizrahi, R.; Rusjan, P.M.; Miler, L.; Rajkowska, G.; Suridjan, I.; Kennedy, J.L.; Rekkas, P.V.; Houle, S.; et al. Role of translocator protein density, a marker of neuroinflammation, in the brain during major depressive episodes. JAMA Psychiatry 2015, 72, 268-275. [CrossRef]

61. Sayana, P.; Pinjari, O.F.; Giridharan, V.V.; Ahmad, N.; da Rosa, M.I.; de Quevedo, J.; Barichello, T. Postmortem evidence of neuroinflammation in bipolar disorder: A systematic review. J. Affect. Disord. 2019, 254, 129. [CrossRef] 
62. Isgren, A.; Sellgren, C.; Ekman, C.J.; Holmen-Larsson, J.; Blennow, K.; Zetterberg, H.; Jakobsson, J.; Landén, M. Markers of neuroinflammation and neuronal injury in bipolar disorder: Relation to prospective clinical outcomes. Brain Behav. Immun. 2017, 65, 195-201. [CrossRef] [PubMed]

63. Data-Franco, J.; Singh, A.; Popovic, D.; Ashton, M.; Berk, M.; Vieta, E.; Figueira, M.L.; Dean, O.M. Beyond the therapeutic shackles of the monoamines: New mechanisms in bipolar disorder biology. Prog. Neuropsychopharmacol. Biol. Psychiatry 2017, 72, 73-86. [CrossRef] [PubMed]

64. Ferro, A.; Bonivento, C.; Delvecchio, G.; Bellani, M.; Perlini, C.; Dusi, N.; Marinelli, V.; Ruggeri, M.; Altamura, A.C.; CrespoFacorro, B.; et al. Longitudinal investigation of the parietal lobe anatomy in bipolar disorder and its association with general functioning. Psychiatry Res. Neuroimaging 2017, 267, 22-31. [CrossRef] [PubMed]

65. Kapczinski, N.S.; Mwangi, B.; Cassidy, R.M.; Librenza-Garcia, D.; Bermudez, M.B.; Kauer-Sant'anna, M.; Kapczinski, F.; Passos, I.C. Neuroprogression and illness trajectories in bipolar disorder. Expert Rev. Neurother. 2017, 17, 277-285. [CrossRef] [PubMed]

66. van den Ameele, S.; Fuchs, D.; Coppens, V.; de Boer, P.; Timmers, M.; Sabbe, B.; Morrens, M. Markers of inflammation and monoamine metabolism indicate accelerated aging in bipolar disorder. Front. Psychiatry 2018, 9, 250. [CrossRef] [PubMed]

67. Cullen, B.; Ward, J.; Graham, N.A.; Deary, I.J.; Pell, J.P.; Smith, D.J.; Evans, J.J. Prevalence and correlates of cognitive impairment in euthymic adults with bipolar disorder: A systematic review. J. Affect. Disord. 2016, 205, 165-181. [CrossRef]

68. Cao, B.; Passos, I.C.; Mwangi, B.; Bauer, I.E.; Zunta-Soares, G.B.; Kapczinski, F.; Soares, J.C. Hippocampal volume and verbal memory performance in late-stage bipolar disorder. J. Psychiatry Res. 2016, 73, 102-107. [CrossRef]

69. Strakowski, S.M.; DelBello, M.P.; Zimmerman, M.E.; Getz, G.E.; Mills, N.P.; Ret, J.; Shear, P.; Adler, C.M. Ventricular and periventricular structural volumes in first-versus multiple-episode bipolar disorder. Am. J. Psychiatry 2002, 159, 1841-1847. [CrossRef]

70. Hibar, D.P.; Westlye, L.T.; Doan, N.T.; Jahanshad, N.; Cheung, J.W.; Ching, C.R.K.; Versace, A.; Bilderbeck, A.C.; Uhlmann, A.; Mwangi, B.; et al. Cortical abnormalities in bipolar disorder: An MRI analysis of 6503 individuals from the ENIGMA Bipolar Disorder Working Group. Mol. Psychiatry 2018, 23, 932-942. [CrossRef]

71. Madireddy, S.; Madireddy, S. Protection from the pathogenesis of neurodegenerative disorders, including alzheimer's disease, amyotrophic lateral sclerosis, Huntington's disease, and Parkinson's diseases, through the mitigation of reactive oxygen species. J. Neurosci. Neurol. Disord. 2019, 3, 148-161. [CrossRef]

72. Tunçel, O.K.; Sarısoy, G.; Bilgici, B.; Pazvantoglu, O.; Çetin, E.; Ünverdi, E.; Avcı, B.; Böke, O. Oxidative stress in bipolar and schizophrenia patients. Psychiatry Res. 2015, 228, 688-694. [CrossRef] [PubMed]

73. Yumru, M.; Savas, H.A.; Kalenderoglu, A.; Bulut, M.; Celik, H.; Erel, O. Oxidative imbalance in bipolar disorder subtypes: A comparative study. Prog. Neuropsychopharmacol. Biol. Psychiatry 2009, 33, 1070-1074. [CrossRef] [PubMed]

74. Guo, C.; Sun, L.; Chen, X.; Zhang, D. Oxidative stress, mitochondrial damage and neurodegenerative diseases. Neural Regen. Res. 2013, 8, 2003-2014.

75. Roda, A.; Chendo, I.; Kunz, M. Biomarkers and staging of bipolar disorder: A systematic review. Trends Psychiatry Psychother. 2015, 37, 3-8. [CrossRef] [PubMed]

76. Salim, S. Oxidative stress and the central nervous system. J. Pharmacol. Exp. Ther. 2017, 360, 201-205. [CrossRef]

77. Phaniendra, A.; Jestadi, D.B.; Periyasamy, L. Free radicals: Properties, sources, targets, and their implication in various diseases Indian J. Clin. Biochem. 2015, 30, 11-26. [CrossRef]

78. Singh, A.; Kukreti, R.; Saso, L.; Kukreti, S. Oxidative stress: A key modulator in neurodegenerative diseases. Molecules 2019, 24, 1583. [CrossRef]

79. Bitanihirwe, B.K.; Woo, T.U. Oxidative stress in schizophrenia: An integrated approach. Neurosci. Biobehav. Rev. 2011, 35, 878-893. [CrossRef]

80. Morris, G.; Puri, B.K.; Walker, A.J.; Berk, M.; Walder, K.; Bortolasci, C.C.; Marx, W.; Carvalho, A.F.; Maes, M. The compensatory antioxidant response system with a focus on neuroprogressive disorders. Prog. Neuropsychopharmacol. Biol. Psychiatry 2019, 95, 109708. [CrossRef]

81. Steckert, A.V.; Valvassori, S.S.; Moretti, M.; Dal-Pizzol, F.; Quevedo, J. Role of oxidative stress in the pathophysiology of bipolar disorder. Neurochem. Res. 2010, 35, 1295-1301. [CrossRef]

82. Younus, H. Therapeutic potentials of superoxide dismutase. Int. J. Health Sci. 2018, 12, 88-93.

83. Collin, F. Chemical basis of reactive oxygen species reactivity and involvement in neurodegenerative diseases. Int. J. Mol. Sci. 2019, 20, 2407. [CrossRef] [PubMed]

84. Lee, H.C.; Wei, Y.H. Mitochondrial biogenesis and mitochondrial DNA maintenance of mammalian cells under oxidative stress Int. J. Biochem. Cell Biol. 2005, 37, 822-834. [CrossRef]

85. Russell, J.W.; Golovoy, D.; Vincent, A.M.; Mahendru, P.; Olzmann, J.A.; Mentzer, A.; Feldman, E.L. High glucose-induced oxidative stress and mitochondrial dysfunction in neurons. FASEB J. 2002, 16, 1738-1748. [CrossRef]

86. Wallace, D.C. A mitochondrial paradigm of metabolic and degenerative diseases, aging, and cancer: A dawn for evolutionary medicine. Annu. Rev. Genet. 2005, 39, 359-407. [CrossRef] [PubMed]

87. Clay, H.; Sillivan, S.; Konradi, C. Mitochondrial dysfunction and pathology in bipolar disorder and schizophrenia. Int. J. Dev. Neurosci. 2011, 29, 311-324. [CrossRef] [PubMed]

88. Madireddy, S.; Madireddy, S. Regulation of reactive oxygen species-mediated damage in the pathogenesis of schizophrenia. Brain Sci. 2020, 10, 742. [CrossRef] 
89. Andreazza, A.C.; Kauer-Sant'Anna, M.; Frey, B.N.; Stertz, L.; Zanotto, C.; Ribeiro, L.; Giasson, K.; Valvassori, S.S.; Réus, G.Z.; Salvador, M.; et al. Effects of mood stabilizers on DNA damage in an animal model of mania. J. Psychiatry Neurosci. 2008, 33, 516-524.

90. Ben-Shachar, D. Mitochondrial dysfunction in schizophrenia: A possible linkage to dopamine. J. Neurochem. 2002, 83, 1241-1251. [CrossRef]

91. Kim, H.K.; Andreazza, A.C. The relationship between oxidative stress and post-translational modification of the dopamine transporter in bipolar disorder. Expert Rev. Neurother. 2012, 12, 849-859. [CrossRef]

92. Halliwell, B. Oxidative stress and neurodegeneration: Where are we now? J. Neurochem. 2006, 97, 1634-1658. [CrossRef]

93. Frey, B.N.; Andreazza, A.C.; Kunz, M.; Gomes, F.A.; Quevedo, J.; Salvador, M.; Gonçalves, C.A.; Kapczinski, F. Increased oxidative stress and DNA damage in bipolar disorder: A twin-case report. Prog. Neuropsychopharmacol. Biol. Psychiatry 2007, 31, 283-285. [CrossRef]

94. Bengesser, S.A.; Lackner, N.; Birner, A.; Fellendorf, F.T.; Platzer, M.; Mitteregger, A.; Unterweger, R.; Reininghaus, B.; Mangge, H.; Wallner-Liebmann, S.J.; et al. Peripheral markers of oxidative stress and antioxidative defense in euthymia of bipolar disorder-Gender and obesity effects. J. Affect. Disord. 2015, 172, 367-374. [CrossRef] [PubMed]

95. Machado-Vieira, R.; Andreazza, A.C.; Viale, C.I.; Zanatto, V.; Cereser, V.; da Silva Vargas, R.; Kapczinski, F.; Portela, L.V.; Souza, D.O.; Salvador, M.; et al. Oxidative stress parameters in unmedicated and treated bipolar subjects during initial manic episode: A possible role for lithium antioxidant effects. Neurosci. Lett. 2007, 421, 33-36. [CrossRef] [PubMed]

96. Andreazza, A.C.; Wang, J.F.; Salmasi, F.; Shao, L.; Young, L.T. Specific subcellular changes in oxidative stress in prefrontal cortex from patients with bipolar disorder. J. Neurochem. 2013, 127, 552-561. [CrossRef] [PubMed]

97. Gawryluk, J.W.; Wang, J.F.; Andreazza, A.C.; Shao, L.; Young, L.T. Decreased levels of glutathione, the major brain antioxidant, in post-mortem prefrontal cortex from patients with psychiatric disorders. Int. J. Neuropsychopharmacol. 2011, 14, 123-130. [CrossRef]

98. Konradi, C.; Sillivan, S.E.; Clay, H.B. Mitochondria, oligodendrocytes and inflammation in bipolar disorder: Evidence from transcriptome studies points to intriguing parallels with multiple sclerosis. Neurobiol. Dis. 2012, 45, 37-47. [CrossRef] [PubMed]

99. Frey, B.N.; Andreazza, A.C.; Houenou, J.; Jamain, S.; Goldstein, B.I.; Frye, M.A.; Leboyer, M.; Berk, M.; Malhi, G.S.; LopezJaramillo, C.; et al. Biomarkers in bipolar disorder: A positional paper from the International Society for Bipolar Disorders Biomarkers Task Force. Aust. N. Z. J. Psychiatry 2013, 47, 321-332. [CrossRef]

100. Kapczinski, F.; Dal-Pizzol, F.; Teixeira, A.L.; Magalhaes, P.V.; Kauer-Sant'Anna, M.; Klamt, F.; Pasquali, M.A.; Quevedo, J.; Gama, C.S.; Post, R. A systemic toxicity index developed to assess peripheral changes in mood episodes. Mol. Psychiatry 2010, 15, 784-786. [CrossRef]

101. Versace, A.; Andreazza, A.C.; Young, L.T.; Fournier, J.C.; Almeida, J.R.; Stiffler, R.S.; Lockovich, J.C.; Aslam, H.A.; Pollock, M.H.; Park, H.; et al. Elevated serum measures of lipid peroxidation and abnormal prefrontal white matter in euthymic bipolar adults: Toward peripheral biomarkers of bipolar disorder. Mol. Psychiatry 2014, 19, 200-208. [CrossRef]

102. Andreazza, A.C.; Gildengers, A.; Rajji, T.K.; Zuzarte, P.M.L.; Mulsant, B.H.; Young, L.T. Oxidative stress in older patients with bipolar disorder. Am. J. Geriatr. Psychiatry 2015, 23, 314-319. [CrossRef]

103. Mahadik, S.P.; Evans, D.; Lal, H. Oxidative stress and role of antioxidant and N-3 essential fatty acid supplementation in schizophrenia. Prog. Neuropsychopharmacol. Biol. Psychiatry 2001, 25, 463-493. [CrossRef]

104. Manji, H.; Kato, T.; DiProspero, N.A.; Ness, S.; Beal, M.F.; Krams, M.; Chen, G. Impaired mitochondrial function in psychiatric disorders. Nat. Rev. Neurosci. 2012, 13, 293-307. [CrossRef] [PubMed]

105. Grintzalis, K.; Zisimopoulos, D.; Grune, T.; Weber, D.; Georgiou, C.D. Method for the simultaneous determination of free/protein malondialdehyde and lipid/protein hydroperoxides. Free Radic. Biol. Med. 2013, 59, 27-35. [CrossRef] [PubMed]

106. de Sousa, R.T.; Zarate, C.A.; Zanetti, M.V.; Costa, A.C.; Talib, L.L.; Gattaz, W.F.; Machado-Vieira, R. Oxidative stress in early-stage bipolar disorder and the association with response to lithium. J. Psychiatry Res. 2014, 50, 36-41. [CrossRef]

107. Yirun, M.C.; Ünal, K.; Şen, N.A.; Yirun, O.; Aydemir, C.; Goka, E. Evaluation of oxidative stress in bipolar disorder in terms of total oxidant status, total antioxidant status, and oxidative stress index. Noro Psikiyatr. Ars. 2016, 53, 194-198. [CrossRef]

108. Siwek, M.; Sowa-Kućma, M.; Dudek, D.; Styczeń, K.; Szewczyk, B.; Kotarska, K.; Misztakk, P.; Pilc, A.; Wolak, M.; Nowak, G. Oxidative stress markers in affective disorders. Pharmacol. Rep. 2013, 65, 1558-1571. [CrossRef]

109. Mohamad Kamal, N.A.; Loo, J.L.; Goon, J.A.; Damanhuri, H.A.; Sharip, S.; Saini, S.M.; Hamzah, J.; Chan, L. Oxidative stress biomarkers in bipolar disorder with suicidal behavior, A systematic review. J. Pharm. Negat. Results 2019, 10, 6-15.

110. Brown, N.C.; Andreazza, A.C.; Young, L.T. An updated meta-analysis of oxidative stress markers in bipolar disorder. Psychiatry Res. 2014, 218, 61-68. [CrossRef]

111. Joshi, Y.B.; Praticò, D. Lipid peroxidation in psychiatric illness: Overview of clinical evidence. Oxid. Med. Cell Longev. 2014, 2014, 828702. [CrossRef]

112. Jiménez-Fernández, S.; Gurpegui, M.; Garrote-Rojas, D.A.; Gutiérrez-Rojas, L.; Carretero, M.D.; Correll, C.U. Oxidative stress parameters and antioxidants in patients with bipolar disorder: Results from a meta-analysis comparing patients, including stratification by polarity and euthymic status, with healthy controls. Bipolar Disord. 2020, 23, 11. [CrossRef] [PubMed]

113. Siwek, M.; Sowa-Kucma, M.; Styczen, K.; Misztak, P.; Szewczyk, B.; Topor-Madry, R.; Nowak, G.; Dudek, D.; Rybakowski, J.K. Thiobarbituric Acid-Reactive Substances: Markers of an Acute Episode and a Late Stage of Bipolar Disorder. Neuropsychobiology 2016, 73, 116-122. [CrossRef] 
114. Andreazza, A.C.; Cassini, C.; Rosa, A.R.; Leite, M.C.; de Almeida, L.M.; Nardin, P.; Cunha, A.B.N.; Ceresér, K.M.; Santin, A.; Gottfried, C.; et al. Serum S100B and antioxidant enzymes in bipolar patients. J. Psychiatr. Res. 2007, 41, 523-529. [CrossRef] [PubMed]

115. Sowa-Kućma, M.; Styczeń, K.; Siwek, M.; Misztak, P.; Nowak, R.J.; Dudek, D.; Rybakowski, J.K.; Nowak, G.; Maes, M. Are there differences in lipid peroxidation and immune biomarkers between major depression and bipolar disorder: Effects of melancholia, atypical depression, severity of illness, episode number, suicidal ideation and prior suicide attempts. Prog. Neuropsychopharmacol. Biol. Psychiatry 2018, 81, 372-383. [CrossRef]

116. Akarsu, S.; Bolu, A.; Aydemir, E.; Zincir, S.B. The relationship between the number of manic episodes and oxidative stress indicators in bipolar disorder. Korean Neuropsychiatr. Assoc. 2018, 15, 514-519. [CrossRef]

117. Andreazza, A.C.; Kapczinski, F.; Kauer-Sant'Anna, M.; Walz, J.C.; Bond, D.J.; Gonçalves, C.A.; Young, L.T.; Yatham, L.N. 3-Nitrotyrosine and glutathione antioxidant system in patients in the early and late stages of bipolar disorder. J. Psychiatry Neurosci. 2009, 34, 263-271.

118. Kunz, M.; Gama, C.S.; Andreazza, A.C.; Salvador, M.; Ceresér, K.M.; Gomes, F.A.; Belmonte-de-Abreu, P.S.; Berk, M.; Kapczinski, F. Elevated serum superoxide dismutase and thiobarbituric acid reactive substances in different phases of bipolar disorder and in schizophrenia. Prog. Neuropsychopharmacol. Biol. Psychiatry 2008, 32, 1677-1681. [CrossRef]

119. Andreazza, A.C.; Frey, B.N.; Erdtmann, B.; Salvador, M.; Goncalves, C.A.; Kapczinski, F. DNA damage in bipolar disorder. Psychiatry Res. 2007, 153, 27-32. [CrossRef] [PubMed]

120. Gergerlioglu, H.S.; Savas, H.A.; Bulbul, F.; Selek, S.; Uz, E.; Yumru, M. Changes in nitric oxide level and superoxide dismutase activity during antimanic treatment. Prog. Neuropsychopharmacol. Biol. Psychiatry 2007, 31, 697-702. [CrossRef]

121. Kato, T. Current understanding of bipolar disorder: Toward integration of biological basis and treatment strategies. Psychiatry Clin. Neurosci. 2019, 73, 526-540. [CrossRef]

122. Mansur, R.B.; Lee, Y.; McIntyre, R.S.; Brietzke, E. What is bipolar disorder? A disease model of dysregulated energy expenditure. Neurosci. Biobehav. Rev. 2020, 113, 529-545. [CrossRef]

123. Singh, N.; McMahon, H.; Bilderbeck, A.; Reed, Z.E.; Tunbridge, E.; Brett, D.; Geddes, J.R.; Churchill, G.C.; Goodwin, G.M. Plasma glutathione suggests oxidative stress is equally present in early- and late-onset bipolar disorder. Bipolar Disord. 2019, 21, 61-67. [CrossRef] [PubMed]

124. Sharma, P.; Jha, A.B.; Dubey, R.S.; Pessarakli, M. Reactive oxygen species, oxidative damage, and antioxidative defense mechanism in plants under stressful conditions. J. Bot. 2012, 2012, 217037. [CrossRef]

125. Wang, Y.; Branicky, R.; Noë, A.; Hekimi, S. Superoxide dismutases: Dual roles in controlling ROS damage and regulating ROS signaling. J. Cell Biol. 2018, 217, 1915-1928. [CrossRef] [PubMed]

126. Bartoli, F.; Crocamo, C.; Mazza, M.G.; Clerici, M.; Carrà, G. Uric acid levels in subjects with bipolar disorder: A comparative meta-analysis. J. Psychiatr. Res. 2016, 81, 133-139. [CrossRef] [PubMed]

127. Chakrabarty, S.; Kabekkodu, S.P.; Singh, R.P.; Thangaraj, K.; Singh, K.K.; Satyamoorthy, K. Mitochondria in health and disease. Mitochondrion 2018, 43, 25-29. [CrossRef] [PubMed]

128. Scaini, G.; Andrews, T.; Lima, C.N.C.; Benevenuto, D.; Streck, E.L.; Quevedo, J. Mitochondrial dysfunction as a critical event in the pathophysiology of bipolar disorder. Mitochondrion 2020, 57, 23-36. [CrossRef] [PubMed]

129. Bhatti, J.S.; Kumar, S.; Vijayan, M.; Bhatti, G.K.; Reddy, P.H. Therapeutic strategies for mitochondrial dysfunction and oxidative stress in age-related metabolic disorders. Prog. Mol. Biol. Transl. Sci. 2017, 146, 13-46.

130. Morris, G.; Walder, K.; McGee, S.L.; Dean, O.M.; Tye, S.J.; Maes, M.; Berk, M. A model of the mitochondrial basis of bipolar disorder. Neurosci. Biobehav. Rev. 2017, 74, 1-20. [CrossRef]

131. Kim, Y.; Santos, R.; Gage, F.H.; Marchetto, M.C. Molecular mechanisms of bipolar disorder: Progress made and future challenges. Front. Cell Neurosci. 2017, 11, 30. [CrossRef]

132. Grimm, A.; Eckert, A. Brain aging and neurodegeneration: From a mitochondrial point of view. J. Neurochem. 2017, 143, 418-431. [CrossRef] [PubMed]

133. Todorova, V.; Blokland, A. Mitochondria and synaptic plasticity in the mature and aging nervous system. Curr. Neuropharmacol. 2017, 15, 166-173. [CrossRef] [PubMed]

134. Niizuma, K.; Yoshioka, H.; Chen, H.; Kim, G.S.; Jung, J.E.; Katsu, M.; Okami, N.; Chan, P.H. Mitochondrial and apoptotic neuronal death signaling pathways in cerebral ischemia. Biochim. Biophys. Acta 2010, 1802, 92-99. [CrossRef] [PubMed]

135. Li, Z.; Okamoto, K.; Hayashi, Y.; Sheng, M. The importance of dendritic mitochondria in the morphogenesis and plasticity of spines and synapses. Cell 2004, 119, 873-887. [CrossRef] [PubMed]

136. Angelova, P.R.; Abramov, A.Y. Role of mitochondrial ROS in the brain: From physiology to neurodegeneration. FEBS Lett. 2018, 592, 692-702. [CrossRef] [PubMed]

137. Kuperberg, M.; Greenebaum, S.L.A.; Nierenberg, A.A. Targeting mitochondrial dysfunction for bipolar disorder. Curr. Top. Behav. Neurosci. 2021, 48, 61-99.

138. Wang, J.-F.; Shao, L.; Sun, X.; Young, L.T. Increased oxidative stress in the anterior cingulate cortex of subjects with bipolar disorder and schizophrenia. Bipolar Disord. 2009, 11, 523-529. [CrossRef]

139. Berk, M.; Turner, A.; Malhi, G.S.; Ng, C.H.; Cotton, S.M.; Dodd, S.; Samuni, Y.; Tanious, M.; McAulay, C.; Dowling, N.; et al. A randomised controlled trial of a mitochondrial therapeutic target for bipolar depression, mitochondrial agents: N-acetylcysteine, and placebo. BMC Med. 2019, 17, 18. 
140. Cikankova, T.; Sigitova, E.; Zverova, M.; Fisar, Z.; Raboch, J.; Hroudova, J. Mitochondrial dysfunctions in bipolar disorder: Effect of the disease and pharmacotherapy. CNS Neurol. Disord. Drug Targets 2017, 16, 176-186. [CrossRef]

141. Scaini, G. Mitochondrial Hypothesis and Its Relationship to Bipolar Disorder. 2019. Available online: https://med.uth.edu/ psychiatry/2019/09/11/mitochondrial-hypothesis-and-its-relationship-to-bipolar-disorder/ (accessed on 12 January 2021).

142. Bhatti, J.S.; Bhatti, G.K.; Reddy, H. Mitochondrial dysfunction and oxidative stress in metabolic disorders-A step towards mitochondria based therapeutic strategies. Biochim. Biophys. Acta Mol. Basis Dis. 2017, 1863, 1066-1077. [CrossRef]

143. Pereira, C.; Chavarria, V.; Vian, J.; Ashton, M.M.; Berk, M.; Marx, W.; Dean, O.M. Mitochondrial agents for bipolar disorder. Int. J. Neuropsychopharmacol. 2018, 21, 550-569. [CrossRef] [PubMed]

144. Scaini, G.; Rezin, G.T.; Carvalho, A.F.; Streck, E.L.; Berk, M.; Quevedo, J. Mitochondrial dysfunction in bipolar disorder: Evidence, pathophysiology and translational implications. Neurosci. Biobehav. Rev. 2016, 68, 694-713. [CrossRef] [PubMed]

145. Soeiro-de-Souza, M.G.; Andreazza, A.C.; Carvalho, A.F.; Machado-Vieira, R.; Young, L.T.; Moreno, R.A. Number of manic episodes is associated with elevated DNA oxidation in bipolar I disorder. Int. J. Neuropsychopharmacol. 2013, 16, $1505-1512$. [CrossRef] [PubMed]

146. Wang, D.; Li, Z.; Liu, W.; Zhou, J.; Ma, X.; Tang, J.; Chen, X. Differential mitochondrial DNA copy number in three mood states of bipolar disorder. BMC Psychiatry 2018, 18, 149. [CrossRef]

147. Munakata, K.; Fujii, K.; Nanko, S.; Kunugi, H.; Kato, T. Sequence and functional analyses of mtDNA in a maternally inherited family with bipolar disorder and depression. Mutat Res. 2007, 617, 119-124. [CrossRef]

148. Chang, C.C.; Jou, S.H.; Lin, T.T.; Liu, C.S. Mitochondrial DNA variation and increased oxidative damage in euthymic patients with bipolar disorder. Psychiatry Clin. Neurosci. 2014, 68, 551-557. [CrossRef]

149. Kasahara, T.; Kato, T. What can mitochondrial DNA analysis tell us about mood disorders? Biol. Psychiatry 2018, 83, 731-738. [CrossRef]

150. Schulmann, A.; Ryu, E.; Goncalves, V.; Rollins, B.; Christiansen, M.; Frye, M.A.; Biernacka, V.M.P. Novel complex interactions between mitochondrial and nuclear DNA in schizophrenia and bipolar disorder. Mol. Neuropsychiatry 2019, 5, 13-27. [CrossRef]

151. Cuperfain, A.B.; Zhang, Z.L.; Kennedy, J.L.; Gonçalves, V.F. The complex interaction of mitochondrial genetics and mitochondrial pathways in psychiatric disease. Mol. Neuropsychiatry 2018, 4, 52-69. [CrossRef]

152. Bhatt, A.H.; Dar, K.B.; Anees, S.; Zargar, M.A.; Masood, A.; Sofi, M.A.; Ganie, S.A. Oxidative stress, mitochondrial dysfunction and neurodegenerative diseases, A mechanistic insight. Biomed. Pharmacother. 2015, 74, 101-110. [CrossRef]

153. Kato, T. The role of mitochondrial dysfunction in bipolar disorder. Drug News Perspect. 2006, 19, 597-602. [CrossRef]

154. Callaly, E.; Walder, K.; Morris, G.; Maes, M.; Debnath, M.; Berk, M. Mitochondrial dysfunction in the pathophysiology of bipolar disorder: Effects of pharmacotherapy. Mini Rev. Med. Chem. 2015, 15, 355-365. [CrossRef]

155. Teixeira, A.L.; Barbosa, I.G.; Machado-Vieira, R.; Rizzo, L.B.; Wieck, A.; Bauer, M.E. Novel biomarkers for bipolar disorder. Expert Opin. Med. Diagn. 2013, 7, 147-159. [CrossRef]

156. Watt, N.T.; Routledge, M.N.; Wild, C.P.; Hooper, N.M. Cellular prion protein protects against reactive-oxygen-species-induced DNA damage. Free Radic. Biol. Med. 2007, 43, 959-967. [CrossRef]

157. Chan, H.W.; Huang, C.Y.; Feng, W.J.; Yen, Y.C. Clinical outcomes of long-acting injectable risperidone in patients with bipolar I disorder: A 1-year retrospective cohort study. J. Affect. Disord. 2016, 205, 360-364. [CrossRef]

158. Wang, D.; Li, H.; Du, X.; Zhou, J.; Yuan, L.; Ren, H.; Yang, X.; Zhang, G.; Chen, X. Circulating brain-derived neurotrophic factor, antioxidant enzymes activities, and mitochondrial DNA in bipolar disorder: An exploratory report. Front. Psychiatry 2020, 11, 514658. [CrossRef]

159. Song, M.; Martinowich, K.; Lee, F.S. BDNF at the synapse: Why location matters. Mol. Psychiatry 2017, 22, 1370-1375. [CrossRef]

160. Fernandes, B.S.; Molendijk, M.L.; Köhler, C.A.; Soares, J.C.; Leite, C.M.; Machado-Vieira, R.; Ribeiro, T.L.; Silva, J.C.; Sales, P.M.G.; Quevedo, J.; et al. Peripheral brain-derived neurotrophic factor (BDNF) as a biomarker in bipolar disorder: A meta-analysis of 52 studies. BMC Med. 2015, 13, 289. [CrossRef]

161. Wu, R.; Fan, J.; Zhao, J.; Calabrese, J.R.; Gao, K. The relationship between neurotrophins and bipolar disorder. Expert Rev. Neurother. 2014, 14, 51-65. [CrossRef]

162. Polyakova, M.; Stuke, K.; Schuemberg, K.; Mueller, K.; Schoenknecht, P.; Schroeter, M.L. BDNF as a biomarker for successful treatment of mood disorders: A systematic \& quantitative meta-analysis. J. Affect. Disord. 2015, 174, 432-440.

163. Lin, P.Y. State-dependent decrease in levels of brain-derived neurotrophic factor in bipolar disorder: A meta-analytic study. Neurosci. Lett. 2009, 466, 139-143. [CrossRef]

164. Kim, H.K.; Mendonça, K.M.; Howson, P.A.; Brotchie, J.M.; Andreazza, A.C. The link between mitochondrial complex I and brain-derived neurotrophic factor in SH-SY5Y cells-The potential of JNX1001 as a therapeutic agent. Eur. J. Pharmacol. 2015, 764, 379-384. [CrossRef]

165. Mansur, R.B.; Santos, C.M.; Rizzo, L.B.; Cunha, G.R.; Asevedo, E.; Noto, M.N.; Pedrini, M.; Zeni, M.; Cordeiro, Q.; McIntyre, R.S.; et al. Inter-relation between brain-derived neurotrophic factor and antioxidant enzymes in bipolar disorder. Bipolar Disord. 2016, 18, 433-439. [CrossRef]

166. Walz, J.C.; Andreazza, A.C.; Frey, B.N.; Cacilhas, A.A.; Ceresér, K.M.M.; Cunha, A.B.M.; Weyne, F.; Stertz, L.; Santin, A.; Gonçalves, C.A.; et al. Serum neurotrophin-3 is increased during manic and depressive episodes in bipolar disorder. Neurosci. Lett. 2007, 415, 87-89. [CrossRef] 
167. Berk, M.; Dodd, S.; Kauer-Sant'anna, M.; Malhi, G.S.; Bourin, M.; Kapczinski, F.; Norman, T. Dopamine dysregulation syndrome: Implications for a dopamine hypothesis of bipolar disorder. Acta Psychiatr. Scand. Suppl. 2007, 434, 41-49. [CrossRef]

168. Haque, E.M.; Asanuma, M.; Higashi, Y.; Miyazaki, I.; Tanaka, K.; Ogawa, N. Apoptosis inducing neurotoxicity of dopamine and its metabolites via reactive quinone generation in neuroblastoma cells. Biochim. Biophys. Acta 2003, 1619, 39-52. [CrossRef]

169. Benes, F.M.; Matzilevich, D.; Burke, R.E.; Walsh, J. The expression of proapoptosis genes is increased in bipolar disorder, but not in schizophrenia. Mol. Psychiatry 2006, 11, 241-251. [CrossRef]

170. Quiroz, J.A.; Gray, N.A.; Kato, T.; Manji, H.K. Mitochondrially mediated plasticity in the pathophysiology and treatment of bipolar disorder. Neuropsychopharmacology 2008, 33, 2551-2565. [CrossRef]

171. Valvassori, S.S.; Bavaresco, D.V.; Feier, G.; Cechinel-Recco, K.; Steckert, A.V.; Varela, R.B.; Borges, C.; Carvalho-Silva, M.; Gomes, L.M.; Streck, E.L.; et al. Increased oxidative stress in the mitochondria isolated from lymphocytes of bipolar disorder patients during depressive episodes. Psychiatry Res. 2018, 264, 192-201. [CrossRef]

172. Ferrie, L.; Young, A.H.; McQuade, R. Effect of lithium and lithium withdrawal on potassium-evoked dopamine release and tyrosine hydroxylase expression in the rat. Int. J. Neuropsychopharmacol. 2006, 9, 729-735. [CrossRef]

173. Himmerich, H.; Bartsch, S.; Hamer, H.; Mergl, R.; Schönherr, J.; Petersein, C.; Munzer, A.; Kirkby, K.C.; Bauer, K.; Sack, U. Modulation of cytokine production by drugs with antiepileptic or mood stabilizer properties in anti-CD3- and anti-CD40stimulated blood in vitro. Oxid. Med. Cell Longev. 2014, 2014, 806162. [CrossRef]

174. Felger, J.C. Imaging the role of inflammation in mood and anxiety-related disorders. Curr. Neuropharmacol. 2018, 16, 533-558. [CrossRef]

175. Mao, R.; Zhang, C.; Chen, J.; Zhao, G.; Zhou, R.; Wang, F.; Xu, J.; Yang, T.; Su, Y.; Huang, J.; et al. Different levels of pro- and anti-inflammatory cytokines in patients with unipolar and bipolar depression. J. Affect. Disord. 2018, 237, 65-72. [CrossRef]

176. Rolstad, S.; Jakobsson, J.; Sellgren, C.; Isgren, A.; Ekman, C.J.; Bjerke, M.; Blennow, K.; Zetterberg, H.; Pålsson, E.; Landén, M. CSF neuroinflammatory biomarkers in bipolar disorder are associated with cognitive impairment. Eur. Neuropsychopharmacol. 2015, 25, 1091-1098. [CrossRef]

177. Sayana, P.; Colpo, G.D.; Simoes, L.R.; Giridharan, V.V.; Teixeira, A.L.; Quevedo, J.; Barichello, T. A systematic review of evidence for the role of inflammatory biomarkers in bipolar patients. J. Psychiatr. Res. 2017, 92, 160e182. [CrossRef]

178. van den Ameele, S.; van Diermen, L.; Staels, W.; Coppens, V.; Dumont, G.; Sabbe, B.; Morrens, M. The effect of mood-stabilizing drugs on cytokine levels in bipolar disorder: A systematic review. J. Affect. Disord. 2016, 203, 364-373. [CrossRef]

179. Barbosa, I.G.; Bauer, M.E.; Machado-Vieira, R.; Teixeira, A.L. Cytokines in bipolar disorder: Paving the way for neuroprogression. Neural. Plast. 2014, 2014, 360481. [CrossRef]

180. Bauer, I.E.; Pascoe, M.C.; Wollenhaupt-Aguiar, B.; Kapczinski, F.; Soares, J.C. Inflammatory mediators of cognitive impairment in bipolar disorder. J. Psychiatr. Res. 2014, 56, 18-27. [CrossRef]

181. Stertz, L.; Magalhaes, P.V.; Kapczinski, F. Is bipolar disorder an inflammatory condition? The relevance of microglial activation. Curr. Opin. Psychiatry 2013, 26, 19-26. [CrossRef]

182. Jones, G.H.; Vecera, C.M.; Pinjari, O.F.; Machado-Vieira, R. Inflammatory signaling mechanisms in bipolar disorder. J. Biomed. Sci. 2021, 28, 45. [CrossRef]

183. Pereira, A.C.; Oliveira, J.; Silva, S.; Madeira, N.; Pereira, C.M.F.; Cruz, M.T. Inflammation in bipolar disorder (BD): Identification of new therapeutic targets. Pharmacol. Res. 2021, 163, 105325. [CrossRef]

184. Young, J.J.; Bruno, D.; Pomara, N. A review of the relationship between proinflammatory cytokines and major depressive disorder. J. Affect. Disord. 2014, 169, 15-20. [CrossRef]

185. Benedetti, F.; Aggio, V.; Pratesi, M.L.; Greco, G.; Furlan, R. Neuroinflammation in bipolar depression. Front. Psychiatry 2020, $11,71$. [CrossRef]

186. Kim, Y.; Jung, H.; Myint, A.; Kim, H.; Park, S. Imbalance between pro-inflammatory and anti-inflammatory cytokines in bipolar disorder. J. Affect. Disord. 2007, 104, 91-95. [CrossRef]

187. Rao, J.S.; Harry, G.J.; Rapoport, S.I.; Kim, H.W. Increased excitotoxicity and neuroinflammatory markers in postmortem frontal cortex from bipolar disorder patients. Mol. Psychiatry 2010, 15, 384-392. [CrossRef]

188. Bezchlibnyk, Y.B.; Wang, J.-F.; McQueen, G.M.; Young, L.T. Gene expression differences in bipolar disorder revealed by cDNA array analysis of post-mortem frontal cortex. J. Neurochem. 2001, 79, 826-834. [CrossRef]

189. Wesseling, H.; Gottschalk, M.G.; Bahn, S. Targeted multiplexed selected reaction monitoring analysis evaluates protein expression changes of molecular risk factors for major psychiatric disorders. Int. J. Neuropsychopharmacol. 2014, 18, 1. [CrossRef]

190. Kageyama, Y.; Kasahara, T.; Kato, M.; Sakai, S.; Deguchi, Y.; Tani, M.; Kuroda, K.; Hattori, K.; Yoshida, S.; Goto, Y.; et al. The relationship between circulating mitochondrial DNA and inflammatory cytokines in patients with major depression. J. Affect. Disord. 2018, 233, 15-20. [CrossRef]

191. Caraci, F.; Spampinato, S.F.; Morgese, M.G.; Tascedda, F.; Salluzzo, M.G.; Giambirtone, M.C.; Caruso, G.; Munafò, A.; Torrisi, S.A.; Leggio, G.M.; et al. Neurobiological links between depression and AD: The role of TGF-beta1 signaling as a new pharmacological target. Pharmacol. Res. 2018, 130, 374-384. [CrossRef]

192. Panaccione, I.; Spalletta, G.; Sani, G. Neuroinflammation and excitatory symptoms in bipolar disorder. Neuroimmunol. Neuroinflam. $2015,2,215-227$. 
193. Rowland, T.; Perry, B.I.; Upthegrove, R.; Barnes, N.; Chatterjee, J.; Gallacher, D.; Marwaha, S. Neurotrophins, cytokines, oxidative stress mediators and mood state in bipolar disorder: Systematic review and meta-analyses. Br. J. Psychiatry 2018, 213, 514-525. [CrossRef]

194. Mondin, T.C.; de Azevedo Cardoso, T.; Moreira, F.P.; Wiener, C.; Oses, J.P.; de Mattos Souza, L.D.; Jansen, K.; da Silva Magalhães, P.V.; Kapczinski, F.; da Silva, R.A. Circadian preferences, oxidative stress and inflammatory cytokines in bipolar disorder: A community study. J. Neuroimmunol. 2016, 301, 23-29. [CrossRef]

195. Solmi, M.; Sharma, M.S.; Osimo, E.F.; Fornaro, M.; Bortolato, B.; Croatto, G.; Miola, A.; Vieta, E.; Pariante, C.M.; Smith, L.; et al. Peripheral levels of C-reactive protein, tumor necrosis factor- $\alpha$, interleukin-6, and interleukin-1 $\beta$ across the mood spectrum in bipolar disorder: A meta-analysis of mean differences and variability. Brain Behav. Immun. 2021, 97, 193-203. [CrossRef]

196. Munkholm, K.; Brauner, J.V.; Kessing, L.V.; Vinberg, M. Cytokines in bipolar disorder vs. healthy control subjects: A systematic review and meta-analysis. J. Psychiatr. Res. 2013, 47, 1119-1133. [CrossRef]

197. Kohler, C.A.; Freitas, T.H.; Maes, M.; de Andrade, N.Q.; Liu, C.S.; Fernandes, B.S.; Stubbs, B.; Solmi, M.; Veronese, N.; Herrmann, N.; et al. Peripheral cytokine and chemokine alterations in depression: A meta-analysis of 82 studies. Acta Psychiatr. Scand. 2017, 135, 373-387. [CrossRef]

198. Beishuizen, A.; Thijs, L.G. Endotoxin and the hypothalamopituitary-adrenal (HPA) axis. J. Endotoxin Res. 2003,9 , 3-24.

199. Harrison, P.J.; Hall, N.; Mould, A.; Al-Juffali, N.; Tunbridge, E.M. Cellular calcium in bipolar disorder: Systematic review and meta-analysis. Mol. Psychiatry 2019, 26, 4106-4116. [CrossRef]

200. Belosludtsev, K.N.; Dubinin, M.V.; Belosludtseva, N.V.; Mironova, G.D. Mitochondrial Ca2 ${ }^{+}$transport: Mechanisms, molecular structures, and role in cells. Biochemistry 2019, 84, 593-607. [CrossRef]

201. Giorgi, C.; Marchi, S.; Pinton, P. The machineries, regulation and cellular functions of mitochondrial calcium. Nat. Rev. Mol. Cell Biol. 2018, 19, 713-730. [CrossRef]

202. Gorlach, A.; Bertram, K.; Hudecova, S.; Krizanova, O. Calcium and ROS: A mutual interplay. Redox Biol. 2015, 6, 260-271. [CrossRef]

203. Ross, W.N. Understanding calcium waves and sparks in central neurons. Nat. Rev. Neurosci. 2012, 13, 157-168. [CrossRef]

204. Joshi, G.; Sultana, R.; Perluigi, M.; Butterfield, D.A. In vivo protection of synaptosomes from oxidative stress mediated by $\mathrm{Fe}^{2+} / \mathrm{H}_{2} \mathrm{O}_{2}$ or 2, 2-azobis-(2-amidinopropane) dihydrochloride by the glutathione mimetic tricyclodecan-9-yl-xanthogenate. Free Radic. Biol. Med. 2005, 38, 1023-1031. [CrossRef] [PubMed]

205. van der Bliek, A.M.; Sedensky, M.M.; Morgan, P.G. Cell biology of the mitochondrion. Genetics 2017, 207, 843-871. [CrossRef] [PubMed]

206. Nicholls, D.G. Mitochondrial calcium function and dysfunction in the central nervous system. Biochim. Biophys. Acta 2009, 1787, 1416-1424. [CrossRef]

207. Fišar, Z.; Hroudová, J.; Singh, N.; Kopřivová, A.; Macecková, D. Effect of simvastatin, coenzyme Q10, resveratrol, acetylcysteine and acetylcarnitine on mitochondrial respiration. Folia Biol. 2016, 62, 53-66.

208. Madireddy, S.; Madireddy, S. The role of diet in maintaining strong brain health by taking the advantage of the gut-brain axis. J. Food Nutr. Res. 2019, 7, 41-50.

209. Olagunju, A.T.; Morgan, J.A.; Aftab, A.; Gatchel, J.R.; Chen, P.; Dols, A.; Sajatovic, M.; Regenold, W.T. A review of the evidence base for nutrition and nutritional supplements in older adults with bipolar disorder: A report from the OABD task force. J. Frailty Aging 2021, 10, 241-246.

210. Ashton, M.M.; Kavanagh, B.E.; Marx, W.; Berk, M.; Sarris, J.; Ng, C.H.; Hopwood, M.; Williams, L.J.; Dean, O.M. A systematic review of nutraceuticals for the treatment of bipolar disorder. Can. J. Psychiatry 2020, 66, 262-273. [CrossRef]

211. Sarris, J.; Murphy, J.; Mischoulon, D.; Papakostas, G.I.; Fava, M.; Berk, M.; Ng, C.H. Adjunctive nutraceuticals for depression: A systematic review and meta-analyses. Am. J. Psychiatry 2016, 173, 575-587. [CrossRef]

212. Madireddy, S.; Madireddy, S. Most effective combination of nutraceuticals for improved memory and cognitive performance in the house cricket, Acheta domesticus. Nutrients 2021, 13, 362. [CrossRef]

213. Ng, F.; Berk, M.; Dean, O.; Bush, A.I. Oxidative stress in psychiatric disorders: Evidence base and therapeutic implications. Int. J. Neuropsychopharmacol. 2008, 21, 1-26. [CrossRef] [PubMed]

214. Pandya, C.D.; Howell, K.R.; Pillai, A.K. Antioxidants as potential therapeutics for neuropsychiatric disorders. Prog. Neuropsychopharmacol. Biol. Psychiatry 2013, 46, 214-223. [CrossRef] [PubMed]

215. Murrough, J.W.; Huryk, K.M.; Mao, X.; Iacoviello, B.; Collins, K.; Nierenberg, A.A.; Kang, G.; Shungu, D.C.; Iosifescu, D.V. A pilot study of minocycline for the treatment of bipolar depression: Effects on cortical glutathione and oxidative stress in vivo. J. Affect. Disord. 2018, 230, 56-64. [CrossRef] [PubMed]

216. Ashton, M.M.; Berk, M.; Ng, C.H.; Hopwood, M.; Kavanagh, B.; Williams, L.J.; Sarris, J.; Dean, O.M. Nutraceuticals and nutritional supplements for the treatment of bipolar disorder: Protocol for a systematic review. BMJ Open 2019, 9, e025640. [CrossRef] [PubMed]

217. Iddir, M.; Brito, A.; Dingeo, G.; Fernandez Del Campo, S.S.; Samouda, H.; La Frano, M.R.; Bohn, T. Strengthening the immune system and reducing inflammation and oxidative stress through diet and nutrition: Considerations during the COVID-19 crisis. Nutrients 2020, 12, 1562. [CrossRef] [PubMed]

218. Boerman, R.; Cohen, D.; Schulte, P.F.; Nugter, A. Prevalence of vitamin D deficiency in adult outpatients with bipolar disorder or schizophrenia. J. Clin. Psychopharmacol. 2016, 36, 588-592. [CrossRef]

219. Naifar, M.; Bouali, M.; Guidara, W.; Ellouze, A.S.; Jmal, K.; Omri, S.; Messedi, M.; Zouari, L.; Elleuch, A.; Maalej, M.; et al. Bipolar disorder vulnerability: The vitamin D path. Can. J. Psychiatry 2020, 65, 184-192. [CrossRef] [PubMed] 
220. Cereda, G.; Enrico, P.; Ciappolino, V.; Delvecchio, G.; Brambilla, P. The role of vitamin D in bipolar disorder: Epidemiology and influence on disease activity. J. Affect. Disord. 2021, 278, 209-217. [CrossRef]

221. Scorza, F.A.; Almeida, A.C.G.; Scorza, C.A.; Moret, M.A.; Finsterer, J. Bipolar disorder: The vitamin D debate. J. Affect. Disord. 2021, 286, 338-339. [CrossRef]

222. Marsh, W.K.; Penny, J.L.; Rothschild, A.J. Vitamin D supplementation in bipolar depression: A double blind placebo-controlled trial. J. Psychiatr. Res. 2017, 95, 48-53. [CrossRef]

223. Geddes, J.R.; Gardiner, A.; Rendell, J.; Voysey, M.; Tunbridge, E.; Hinds, C.; Yu, L.; Hainsworth, J.; Attenburrow, M.; Simon, J.; et al. Comparative evaluation of quetiapine plus lamotrigine combination versus quetiapine monotherapy (and folic acid versus placebo) in bipolar depression (cequel): A $2 \times 2$ factorial randomised trial. Lancet Psychiatry 2016, 3, 31-39. [CrossRef]

224. Crider, K.S.; Yang, T.P.; Berry, R.J.; Bailey, L.B. Folate and DNA methylation: A review of molecular mechanisms and the evidence for folate's role. Adv. Nutr. 2012, 3, 21-38. [CrossRef]

225. Morris, D.W.; Trivedi, M.H.; Rush, A.J. Folate and unipolar depression. J. Altern. Complement. Med. 2008, 14, 277-285. [CrossRef] [PubMed]

226. Łojko, D.; Stelmach, M.; Suwalska, A. Is diet important in bipolar disorder? Psychiatry Pol. 2018, 52, 783-795. [CrossRef]

227. Behzadi, A.H.; Omrani, Z.; Chalian, M.; Asadi, S.; Ghadiri, M. Folic acid efficacy as an alternative drug added to sodium valproate in the treatment of acute phase of mania in bipolar disorder: A double-blind randomized controlled trial. Acta Psychiatr. Scand. 2009, 120, 441-445. [CrossRef]

228. Nierenberg, A.A.; Montana, R.; Kinrys, G.; Deckersbach, T.; Dufour, S.; Baek, J.H. L-Methylfolate for bipolar I depressive episodes: An open trial proof-of-concept registry. J. Affect. Disord. 2017, 207, 429-433. [CrossRef] [PubMed]

229. Siwek, M.; Styczeń, K.; Sowa-Kućma, M.; Dudek, D.; Reczyński, W.; Szewczyk, B.; Misztak, P.; Opoka, W.; Topór-Mądry, R.; Nowak, G. The serum concentration of magnesium as a potential state marker in patients with diagnosis of bipolar disorder. Psychiatr. Pol. 2015, 49, 1277-1287. [CrossRef]

230. Siwek, M.; Styczeń, K.; Sowa-Kućma, M.; Dudek, D.; Reczyński, W.; Szewczyk, B.; Misztak, P.; Opoka, W.; Topór-Mądry, R.; Nowak, G.; et al. The serum concentration of copper in bipolar disorder. Psychiatr. Pol. 2017, 51, 469-481. [CrossRef]

231. Koga, N.; Ogura, J.; Yoshida, F.; Hattori, K.; Hori, H.; Aizawa, E.; Ishida, I.; Kunugi, H. Altered polyunsaturated fatty acid levels in relation to proinflammatory cytokines, fatty acid desaturase genotype, and diet in bipolar disorder. Transl. Psychiatry 2019, 9 , 208. [CrossRef]

232. McNamara, R.K.; Welge, J.A. Meta-analysis of erythrocyte polyunsaturated fatty acid biostatus in bipolar disorder. Bipolar Disord. 2016, 18, 300-306. [CrossRef]

233. Fusar-Poli, L.; Surace, T.; Vanella, A.; Meo, V.; Patania, F.; Furnari, R.; Signorelli, M.S.; Aguglia, E. The effect of adjunctive nutraceuticals in bipolar disorder: A systematic review of randomized placebo-controlled trials. J. Affect. Disord. 2019, 252, 334-349. [CrossRef]

234. Rakofsky, J.J.; Dunlop, B.W. Review of nutritional supplements for the treatment of bipolar depression. Depress. Anxiety 2014, 31, 379-390. [CrossRef]

235. Balanza-Martinez, V.; Fries, G.R.; Colpo, G.D.; Silveira, P.P.; Portella, A.K.; Tabares-Seisdedos, R.; Kapczinski, F. Therapeutic use of omega-3 fatty acids in bipolar disorder. Expert Rev. Neurother. 2011, 11, 1029-1047. [CrossRef]

236. Saunders, E.F.H.; Ramsden, C.E.; Sherazy, M.S.; Gelenberg, A.J.; Davis, J.M.; Rapoport, S.I. Omega-3 and omega-6 polyunsaturated fatty acids in bipolar disorder: A review of biomarker and treatment studies. J. Clin. Psychiatry 2016, 77, e1301-e1308. [CrossRef]

237. Lange, K.W. Omega-3 fatty acids and mental health. Glob. Health J. 2020, 4, 18-30. [CrossRef]

238. Husain, M.I.; Strawbridge, R.; Stokes, P.R.A.; Young, A.H. Anti-inflammatory treatments for mood disorders: Systematic review and meta-analysis. J. Psychopharmacol. 2017, 31, 1137-1148. [CrossRef]

239. Bloch, M.H.; Hannestad, J. Omega-3 fatty acids for the treatment of depression: Systematic review and meta-analysis. Mol. Psychiatry 2012, 17, 1272-1282. [CrossRef]

240. Rosenblat, J.D.; McIntyre, R.S. Bipolar disorder and immune dysfunction: Epidemiological findings, proposed pathophysiology and clinical implications. Brain Sci. 2017, 7, 144. [CrossRef]

241. Wilczynska, A. Fatty acids in treatment and prevention of depression. Psychiatr. Pol. 2013, 47, 657-666.

242. Beyer, J.L.; Payne, M.E. Nutrition and bipolar depression. Psychiatr. Clin. N. Am. 2016, 39, 75-86. [CrossRef]

243. Sarris, J. Clinical use of nutraceuticals in the adjunctive treatment of depression in mood disorders. Australas. Psychiatry 2017, 25, 369-372. [CrossRef]

244. McPhilemy, G.; Byrne, F.; Waldron, M.; Hibbeln, J.R.; Davis, J.; McDonald, C.; Hallahan, B. A 52-week prophylactic randomised control trial of omega-3 polyunsaturated fatty acids in bipolar disorder. Bipolar Disord. 2020, 23, 697-706. [CrossRef]

245. Ciappolino, V.; DelVecchio, G.; Prunas, C.; Andreella, A.; Finos, L.; Caletti, E.; Siri, F.; Mazzocchi, A.; Botturi, A.; Turolo, S.; et al. The effect of DHA supplementation on cognition in patients with bipolar disorder: An exploratory randomized control trial. Nutrients 2020, 12, 708. [CrossRef]

246. Kaulmann, A.; Bohn, T. Carotenoids, inflammation, and oxidative stress-implications of cellular signaling pathways and relation to chronic disease prevention. Nutr. Res. 2014, 34, 907-929. [CrossRef]

247. Rubin, L.P.; Ross, A.C.; Stephensen, C.B.; Bohn, T.; Tanumihardjo, S.A. Metabolic effects of inflammation on vitamin A and carotenoids in humans and animal models. Adv. Nutr. 2017, 8, 197-212. [CrossRef] 
248. Wannamethee, S.G.; Lowe, G.D.; Rumley, A.; Bruckdorfer, K.R.; Whincup, P.H. Associations of vitamin C status, fruit and vegetable intakes, and markers of inflammation and hemostasis. Am. J. Clin. Nutr. 2006, 83, 567-574. [CrossRef]

249. Bozonet, S.M.; Carr, A.C.; Pullar, J.M.; Vissers, M.C. Enhanced human neutrophil vitamin C status, chemotaxis and oxidant generation following dietary supplementation with vitamin C-rich SunGold kiwifruit. Nutrients 2015, 7, 2574-2588. [CrossRef]

250. Carr, A.C.; Maggini, S. Vitamin C and immune function. Nutrients 2017, 9, 1211. [CrossRef]

251. Rosenblat, J.D.; Gregory, J.M.; McIntyre, R.S. Pharmacologic implications of inflammatory comorbidity in bipolar disorder. Curr. Opin. Pharmacol. 2016, 29, 63-69. [CrossRef]

252. Berk, M.; Dean, O.M.; Cotton, S.M.; Gama, C.S.; Kapczinski, F.; Fernandes, B.; Kohlmann, K.; Jeavons, S.; Hewitt, K.; Moss, K.; et al. Maintenance $\mathrm{N}$-acetyl cysteine treatment for bipolar disorder: A double-blind randomized placebo-controlled trial. $B M C$ Med. 2012, 10, 91. [CrossRef]

253. Berk, M.; Copolov, D.L.; Dean, O.; Lu, K.; Jeavons, S.; Schapkaitz, I.; Anderson-Hunt, M.; Bush, A.I. Nacetyl cysteine for depressive symptoms in bipolar disorder-A double-blind randomized placebocontrolled trial. Biol. Psychiatry 2008, 64, 468-475. [CrossRef]

254. Zhang, Z.; Zhang, Z.Y.; Wu, Y.; Schluesener, H.J. Valproic acid ameliorates inflammation in experimental autoimmune encephalomyelitis rats. Neuroscience 2012, 221, 140-150. [CrossRef]

255. Amirzargar, M.A.; Yaghubi, F.; Hosseinipanah, M.; Jafari, M.; Pourjafar, M.; Rezaeepoor, M.; Rezaei, H.; Roshanaei, G.; Hajilooi, M.; Solgi, G. Anti-inflammatory effects of valproic acid in a rat model of renal ischemia/reperfusion injury: Alteration in cytokine profile. Inflammation 2017, 40, 1310-1318. [CrossRef]

256. Fountoulakis, K.N.; Grunze, H.; Vieta, E.; Young, A.; Yatham, L.; Blier, P.; Kasper, S.; Moeller, H.J. The international college of neuro-psychopharmacology (CINP) treatment guidelines for bipolar disorder in adults (CINP-BD-2017), Part 3, the clinical guidelines. Int. J. Neuropsychopharmacol. 2017, 20, 180-195. [CrossRef]

257. Yatham, L.N.; Kennedy, S.H.; Parikh, S.V.; Schaffer, A.; Bond, D.J.; Frey, B.N.; Sharma, V.; Goldstein, B.I.; Rej, S.; Beaulieu, S.; et al Canadian network for mood and anxiety treatments (CANMAT) and international society for bipolar disorders (ISBD) 2018 guidelines for the management of patients with bipolar disorder. Bipolar Disord. 2018, 20, 97-170. [CrossRef]

258. Baldessarini, R.J.; Vazquez, G.H.; Tondo, L. Bipolar depression, A major unsolved challenge. Int. J. Bipolar Disord. 2020, 8, 1. [CrossRef]

259. Malhi, G.S.; Gessler, D.; Outhred, T. Use of lithium for treatment of bipolar disorder: Recommendations from clinical practice guidelines. J. Affect. Disord. 2017, 217, 266-280. [CrossRef]

260. Benard, V.; Vaiva, G.; Masson, M.; Geoffroy, P.A. Lithium and suicide prevention in bipolar disorder. Encephale 2016, 42, $234-241$. [CrossRef]

261. Cipriani, A.; Hawton, K.; Stockton, S.; Geddes, J.R. Lithium in the prevention of suicide in mood disorders: Updated systematic review and meta-analysis. BMJ 2013, 346, f3646. [CrossRef]

262. Sani, G.; Fiorillo, A. The use of lithium in mixed states. CNS Spectr. 2019, 25, 449-451. [CrossRef]

263. Kapur, V.; Nadella, R.K.; Raghuraman, B.S.; Saraf, G.; Mishra, S.; Srinivasmurthy, N.; Jain, S.; Zompo, M.D.; Viswanath, B. Clinical factors associated with lithium treatment response in bipolar disorder patients from India. Asian J. Psychiatr. 2019, 39, 165-168. [CrossRef]

264. Paul, P.; Iyer, S.; Nadella, R.K.; Nayak, R.; Chellappa, A.S.; Ambardar, S.; Sud, R.; Sukumaran, S.K.; Purushottam, M.; Jain, S.; et al. Lithium response in bipolar disorder correlates with improved cell viability of patient derived cell lines. Sci. Rep. 2020, 10, 7428. [CrossRef]

265. Jauhar, S.; Young, A.H. Controversies in bipolar disorder; role of second-generation antipsychotic for maintenance therapy. Int. J. Bipolar Disord. 2019, 7, 10. [CrossRef]

266. Severus, E.; Bauer, M.; Geddes, J. Efficacy and effectiveness of lithium in the long-term treatment of bipolar disorders: An update 2018. Pharmacopsychiatry 2018, 51, 173-176. [CrossRef]

267. Sato, K. Why is lithium effective in alleviating bipolar disorder? Med. Hypotheses 2021, 147, 110484. [CrossRef]

268. Luu, B.; Rodway, G. Lithium therapy for bipolar disorder. J. Nurse Pract. 2018, 14, 93-99. [CrossRef]

269. Girardi, P.; Brugnoli, R.; Manfredi, G.; Sani, G. Lithium in bipolar disorder: Optimizing therapy using prolonged-release formulations. Drugs RED 2016, 16, 293-302.

270. Carvalho, A.; Firth, J.; Vieta, E. Bipolar disorder. N. Engl. J. Med. 2020, 383, 58-66. [CrossRef]

271. de Mendiola, P.X.; Hidalgo-Mazzei, D.; Vieta, E.; González-Pinto, A. Overview of lithium's use: A nationwide survey. Int. J. Bipolar Disord. 2021, 9, 10. [CrossRef]

272. Parabiaghi, A.; Barbato, A.; Risso, P.; Fortino, I.; Bortolotti, A.; Merlino, L.; D’Avanzo, B. Lithium use from 2000 to 2010 in Italy: A population-based study. Pharmacopsychiatry 2015, 48, 89-94. [CrossRef]

273. Renes, J.W.; Regeer, E.J.; Hoogendoorn, A.W.; Nolen, W.A.; Kupka, R.W. A nationwide study on concordance with multimodal treatment guidelines in bipolar disorder. Int. J. Bipolar Disord. 2018, 6, 22. [CrossRef]

274. Rhee, T.G.; Olfson, M.; Nierenberg, A.A.; Wilkinson, S.T. 20-Year trends in the pharmacologic treatment of bipolar disorder by psychiatrists in outpatient care settings. Am. J. Psychiatry 2020, 177, 706-715. [CrossRef]

275. Lazzara, C.A.; Kim, Y.H. Potential application of lithium in Parkinson's and other neurodegenerative diseases. Front. Neurosci. 2015, 9, 403. [CrossRef]

276. Morris, G.; Berk, M. The putative use of lithium in Alzheimer's disease. Curr. Alzheimer Res. 2016, 13, 853-861. [CrossRef]

277. Murru, A.; Manchia, M.; Hajek, T.; Nielsen, R.E.; Rybakowski, J.K.; Sani, G.; Schulze, T.G.; Tondo, L.; Bauer, M. Lithium's antiviral effects: A potential drug for COVID-19 disease? Int. J. Bipolar Disord. 2020, 8, 21. [CrossRef] 
278. van Gestel, H.; Franke, K.; Petite, J.; Slaney, C.; Garnham, J.; Helmick, C.; Johnson, K.; Uher, R.; Alda, M.; Hajek, T. Brain age in bipolar disorders: Effects of lithium treatment. Aust. N. Z. J. Psychiatry 2019, 53, 1179-1188. [CrossRef]

279. Alqahtani, S.; Aljuma'ah, N.; Aydan, N.B.; Alsultan, A.; Alsarhani, E.; Asiri, Y. Estimation of lithium clearance in patients with bipolar disorder. Int. Clin. Psychopharmacol. 2020, 35, 157-162. [CrossRef]

280. Andrade, C. Lithium levels and treatment efficacy. Bipolar Disord. 2020, 22, 89-90. [CrossRef]

281. Ommati, M.M.; Niknahad, H.; Farshad, O.; Azarpira, N.; Heidari, R. In vitro and in vivo evidence on the role of mitochondrial impairment as a mechanism of lithium-induced nephrotoxicity. Biol. Trace Elem. Res. 2021, 199, 1908-1918. [CrossRef]

282. Morris, G.; Berk, M. The many roads to mitochondrial dysfunction in neuroimmune and neuropsychiatric disorders. BMC Med. 2015, 13, 68. [CrossRef]

283. Elvsåshagen, T.; Vera, E.; Bøen, E.; Bratlie, J.; Andreassen, O.A.; Josefsen, D.; Malt, U.F.; Blasco, M.A.; Boye, B. The load of short telomeres is increased and associated with lifetime number of depressive episodes in bipolar II disorder. J. Affect. Disord. 2011, 135, 43-50. [CrossRef]

284. Khairova, R.; Pawar, R.; Salvadore, G.; Juruena, M.F.; de Sousa, R.T.; Soeiro-de-Souza, M.G.; Salvador, M.; Zarate, C.A.; Gattaz, W.F.; Machado-Vieira, R. Effects of lithium on oxidative stress parameters in healthy subjects. Mol. Med. Rep. $2012,5,680-682$.

285. Lundberg, M.; Millischer, V.; Backlund, L.; Martinsson, L.; Stenvinkel, P.; Sellgren, C.M.; Lavebratt, C.; Schalling, M. Lithium and the interplay between telomeres and mitochondria in bipolar disorder. Front. Psychiatry 2020, 11, 586083. [CrossRef]

286. Barjasteh-Askari, F.; Davoudi, M.; Amini, H.; Ghorbani, M.; Yaseri, M.; Yunesian, M.; Mahvi, A.H.; Lester, D. Relationship between suicide mortality and lithium in drinking water: A systematic review and meta-analysis. J. Affect. Disord. 2020, 264, 234-241. [CrossRef]

287. Lv, Q.; Guo, Y.; Zhu, M.; Geng, R.; Cheng, X.; Bao, C.; Wang, Y.; Huang, X.; Zhang, C.; Hao, Y.; et al. Predicting individual responses to lithium with oxidative stress markers in drug-free bipolar disorder. World J. Biol. Psychiatry 2019, 20, 778-789. [CrossRef]

288. Smith, K.A.; Cipriani, A. Lithium and suicide in mood disorders: Updated meta-review of the scientific literature. Bipolar Disord. 2017, 19, 575-586. [CrossRef]

289. Song, J.; Sjölander, A.; Joas, E.; Bergen, S.E.; Runeson, B.; Larsson, H.; Landén, M.; Lichtenstein, P. Suicidal behavior during lithium and valproate treatment: A within-individual 8-year prospective study of 50,000 patients with bipolar disorder. Am. J. Psychiatry 2017, 174, 795-802. [CrossRef]

290. Post, R.M. The new news about lithium: An underutilized treatment in the United States. Neuropsychopharmacology 2018, 43, 1174-1179. [CrossRef]

291. Rybakowski, J.K. Challenging the negative perception of lithium and optimizing its long-term administration. Front. Mol. Neurosci. 2018, 11, 349. [CrossRef]

292. Machado-Vieira, R. Lithium, stress, and resilience in bipolar disorder: Deciphering this key homeostatic synaptic plasticity regulator. J. Affect. Disord. 2018, 233, 92-99. [CrossRef]

293. Morsel, A.M.; Morrens, M.; Sabbe, B. An overview of pharmacotherapy for bipolar I disorder. Expert Opin. Pharmacother. 2018, 19, 203-222. [CrossRef]

294. Vasudev, A.; Chaudhari, S.; Sethi, R.; Fu, R.; Sandieson, R.M.; Forester, B.P. A review of the pharmacological and clinical profile of newer atypical antipsychotics as treatments for bipolar disorder: Considerations for use in older patients. Drugs Aging 2018, 35, 887-895. [CrossRef]

295. Maddu, N.; Raghavendra, P.B. Review of lithium effects on immune cells. Immunopharmacol. Immunotoxicol. 2015, 37, 111-125. [CrossRef]

296. Nassar, A.; Azab, A.N. Effects of lithium on inflammation. ACS Chem. Neurosci. 2014, 5, 451-458. [CrossRef]

297. Valvassori, S.S.; Resende, W.R.; Dal-Pont, G.; Sangaletti-Pereira, H.; Gava, F.F.; Peterle, B.R.; Carvalho, A.F.; Varela, R.B.; Dal-Pizzol, F.; Quevedo, J. Lithium ameliorates sleep deprivation-induced mania-like behavior, hypothalamic-pituitary-adrenal (HPA) axis alterations, oxidative stress and elevations of cytokine concentrations in the brain and serum of mice. Bipolar Disord. 2017, 19, 246-258. [CrossRef]

298. Muneer, A. Bipolar disorder: Role of inflammation and the development of disease biomarkers. Psychiatry Investig. 2016, 13, 18-33. [CrossRef]

299. Nahman, S.; Belmaker, R.H.; Azab, A.N. Effects of lithium on lipopolysacchride-induced inflammation in rat primary glial cells. Innate Immun. 2012, 18, 447-458. [CrossRef]

300. Kang, K.; Kim, Y.J.; Kim, Y.H.; Roh, J.N.; Nam, J.M.; Kim, P.Y.; Ryu, W.-S.; Lee, S.-H.; Yoon, B.-W. Lithium pretreatment reduces brain injury after intracerebral hemorrhage in rats. Neurol. Res. 2012, 34, 447-454. [CrossRef]

301. Won, E.; Kim, Y.K. An oldie but goodie: Lithium in the treatment of bipolar disorder through neuroprotective and neurotrophic mechanisms. Int. J. Mol. Sci. 2017, 18, 2679. [CrossRef]

302. Machado-Vieira, R.; Manji, H.K.; Zarate, C.A. The role of lithium in the treatment of bipolar disorder: Convergent evidence for neurotrophic effects as a unifying hypothesis. Bipolar Disord. 2009, 11, 92-109. [CrossRef]

303. Najt, P.; Bayer, U.; Hausmann, M. Right fronto-parietal dysfunction underlying spatial attention in bipolar disorder. Psychiatry Res. 2013, 210, 479-484. [CrossRef] [PubMed]

304. Maurer, I.C.; Schippel, P.; Volz, H.P. Lithium-induced enhancement of mitochondrial oxidative phosphorylation in human brain tissue. Bipolar Disord. 2009, 11, 515-522. [CrossRef] [PubMed] 
305. de Sousa, R.T.; Streck, E.L.; Zanetti, M.V.; Ferreira, G.K.; Diniz, B.S.; Brunoni, A.R.; Busatto, G.F.; Gattaz, W.F.; Machado-Vieira, R. Lithium increases leukocyte mitochondrial complex I activity in bipolar disorder during depressive episodes. Psychopharmacology 2015, 232, 245-250. [CrossRef] [PubMed]

306. Adams, W.K.; Levesque, D.L.; Cocker, P.J.; Kaur, S.; Bodnar, T.S.; Young, A.H.; Winstanley, C.A. Decreased motor impulsivity following chronic lithium treatment in male rats is associated with reduced levels of pro-inflammatory cytokines in the orbitofrontal cortex. Brain Behav. Immun. 2020, 89, 339-349. [CrossRef] [PubMed]

307. Berk, M.; Dandash, O.; Daglas, R.; Cotton, S.M.; Allott, K.; Fornito, A.; Suo, C.; Klauser, P.; Liberg, B.; Henry, L.; et al Neuroprotection after a first episode of mania: A randomized controlled maintenance trial comparing the effects of lithium and quetiapine on grey and white matter volume. Transl. Psychiatry 2017, 7, e1011. [CrossRef] [PubMed]

308. González-Pinto, A.; López-Peña, P.; Bermúdez-Ampudia, C.; Vieta, E.; Martinez-Cengotitabengoa, M. Can lithium salts prevent depressive episodes in the real world? Eur. Neuropsychopharmacol. 2018, 28, 1351-1359. [CrossRef] [PubMed]

309. Kessing, L.V.; Bauer, M.; Nolen, W.A.; Severus, E.; Goodwin, G.M.; Geddes, J. Effectiveness of maintenance therapy of lithium vs. other mood stabilizers in monotherapy and in combinations: A systematic review of evidence from observational studies. Bipolar Disord. 2018, 20, 419-431. [CrossRef] [PubMed]

310. Lahteenvuo, M.; Tanskanen, A.; Taipale, H.; Hoti, F.; Vattulainen, P.; Vieta, E.; Tiihonen, J. Real-world effectiveness of pharmacologic treatments for the prevention of rehospitalization in a finnish nationwide cohort of patients with bipolar disorder. JAMA Psychiatry 2018, 75, 347-355. [CrossRef]

311. Miura, T.; Noma, H.; Furukawa, T.A.; Mitsuyasu, H.; Tanaka, S.; Stockton, S.; Salanti, G.; Motomura, K.; Shimano-Katsuki, S.; Leucht, S.; et al. Comparative efficacy and tolerability of pharmacological treatments in the maintenance treatment of bipolar disorder: A systematic review and network meta-analysis. Lancet Psychiatry 2014, 1, 351-359. [CrossRef]

312. Severus, E.; Taylor, M.J.; Sauer, C.; Pfennig, A.; Ritter, P.; Bauer, M.; Geddes, J.R. Lithium for prevention of mood episodes in bipolar disorders: Systematic review and meta-analysis. Int. J. Bipolar Disord. 2014, 2, 15. [CrossRef]

313. Hjerde, E.; Dahl, S.G.; Sylte, I. Atypical and typical antipsychotic drug interactions with the dopamine D2 receptor. Eur. J. Med. Chem. 2005, 40, 185-194. [CrossRef] [PubMed]

314. Vacheron-Trystram, M.N.; Braitman, A.; Cheref, S.; Auffray, L. Antipsychotics in bipolar disorders. Encephale 2004, 30, 417-424 [CrossRef]

315. Bessonova, L.; Velligan, D.I.; Weiden, P.J.; O'Sullivan, A.K.; Yarlas, A.; Bayliss, M.; Baranwal, N.; Rychlec, K.; Carpenter-Conlin, J.; Doane, M.J.; et al. Antipsychotic treatment experiences of people with bipolar I disorder: Patient perspectives from an online survey. BMC Psychiatry 2020, 20, 354. [CrossRef] [PubMed]

316. Cipriani, A.; Rendell, J.; Geddes, J.R. Olanzapine in the long-term treatment of bipolar disorder: A systematic review and meta-analysis. J. Psychopharmacol. 2010, 24, 1729-1738. [CrossRef]

317. Malhi, G.S.; Bassett, D.; Boyce, P.; Bryant, R.; Fitzgerald, P.B.; Fritz, K.; Hopwood, M.; Lyndon, B.; Mulder, R.; Murray, G.; et al Royal Australian and New Zealand college of psychiatrists clinical practice guidelines for mood disorders. Aust. N. Z. J. Psychiatry 2015, 49, 1087-1206. [CrossRef]

318. López-Muñoz, F.; Shen, W.W.; D’Ocon, P.; Romero, A.; Álamo, C. A history of the pharmacological treatment of bipolar disorder. Int. J. Mol. Sci. 2018, 19, 2143. [CrossRef]

319. Derry, S.; Moore, R.A. Atypical antipsychotics in bipolar disorder: Systematic review of randomized trials. BMC Psychiatry 2007, 7, 40. [CrossRef]

320. Earley, W.; Burgess, M.V.; Rekeda, L.; Dickinson, R.; Szatmári, B.; Németh, G.; McIntyre, R.S.; Sachs, G.S.; Yatham, L.N. Cariprazine treatment of bipolar depression: A randomized double-blind placebo-controlled phase 3 study. Am. J. Psychiatry 2019, 176, 439-448. [CrossRef]

321. Cichoń, L.; Janas-Kozik, M.; Siwiec, A.; Rybakowski, J.K. Clinical picture and treatment of bipolar affective disorder in children and adolescents. Psychiatry Pol. 2020, 54, 35-50. [CrossRef]

322. Gammon, D.; Cheng, C.; Volkovinskaia, A.; Baker, G.B.; Dursun, S.M. Clozapine: Why is it so uniquely effective in the treatment of a range of neuropsychiatric disorders? Biomolecules 2021, 11, 1030. [CrossRef]

323. Renzenbrink, M.; Wand, A.P.F. A systematic review of clozapine's effectiveness for primary psychotic and bipolar disorders in older adults. Int. Psychogeriatr. 2021, 1-13. [CrossRef] [PubMed]

324. Delgado, A.; Velosa, J.; Zhang, J.; Dursun, S.M.; Kapczinski, F.; de Azevedo Cardoso, T. Clozapine in bipolar disorder: A systematic review and meta-analysis. J. Psychiatr. Res. 2020, 125, 21-27. [CrossRef] [PubMed]

325. Li, X.B.; Tang, Y.L.; Wang, C.Y.; Leon, J. Clozapine for treatment-resistant bipolar disorder, A systematic review. Bipolar Disord. 2015, 17, 235-247. [CrossRef] [PubMed]

326. Ifteni, P.; Teodorescu, A.; Moga, M.A.; Pascu, A.M.; Miclaus, R.S. Switching bipolar disorder patients treated with clozapine to another antipsychotic medication: A mirror image study. Neuropsychiatr. Dis. Treat. 2017, 13, 201-204. [CrossRef]

327. Wilkowska, A.; Wiglusz, M.S.; Cubała, W.J. Clozapine in treatment-resistant bipolar disorder with suicidality. Three case reports. Front. Psychiatry 2019, 10, 520. [CrossRef]

328. Benazzi, F.; Berk, M.; Frye, M.A.; Wang, W.; Barraco, A.; Tohen, M. Olanzapine/fluoxetine combination for the treatment of mixed depression in bipolar I disorder: A post hoc analysis. J. Clin. Psychiatry 2009, 70, 1424-1431. [CrossRef]

329. Macfadden, W.; Adler, C.M.; Turkoz, I.; Haskins, J.T.; Turner, N.; Alphs, L. Adjunctive long-acting risperidone in patients with bipolar disorder who relapse frequently and have active mood symptoms. BMC Psychiatry 2011, 11, 171. [CrossRef] 
330. Saxena, K.; Chang, K.; Steiner, H. Treatment of aggression with risperidone in children and adolescents with bipolar disorder: A case series. Bipolar Disord. 2006, 8, 405-410. [CrossRef]

331. Biederman, J.; Mick, E.; Wozniak, J.; Aleardi, M.; Spencer, T.; Faraone, S.V. An open-label trial of risperidone in children and adolescents with bipolar disorder. J. Child Adolesc. Psychopharmacol. 2005, 15, 311-317. [CrossRef]

332. Stahl, S.M. Mechanism of action of cariprazine. CNS Spectr. 2016, 21, 123-127. [CrossRef]

333. Citrome, L. Cariprazine in bipolar disorder: Clinical efficacy, tolerability, and place in therapy. Adv. Ther. 2013, 30, 102-113. [CrossRef] [PubMed]

334. Roberts, R.J.; Findlay, L.J.; El-Mallakh, P.L.; El-Mallakh, R.S. Update on schizophrenia and bipolar disorder: Focus on cariprazine. Neuropsychiatr. Dis. Treat 2016, 12, 1837-1842. [PubMed]

335. Edinoff, A.; Ruoff, M.T.; Ghaffar, Y.T.; Rezayev, A.; Jani, D.; Kaye, A.M.; Cornett, E.M.; Kaye, A.D.; Viswanath, O.; Urits, I. Cariprazine to treat schizophrenia and bipolar disorder in adults. Psychopharmacol. Bull. 2020, 50, 83-117. [PubMed]

336. Silfstein, M.; Abi-Dargham, A.; D’Souza, D.C.; Carson, R.E.; Laszlovszky, I.; Durgam, S.; Adham, N.; Kiss, B. Cariprazine demonstrates high dopamine D3 and D2 receptor occupancy in patients with schizophrenia: A clinical PET study with [11C]-(+)PHNO. Neuropharmacology 2013, 38, S520.

337. Kiss, B.; Horti, F.; Bobok, A. In vitro and in vivo comparison of $[3 \mathrm{H}](+)-\mathrm{PHNO}$ and $[3 \mathrm{H}]$ raclopride binding to rat striatum and lobes 9 and 10 of the cerebellum: A method to distinguish dopamine D3 from D2 receptor sites. Synapse 2011, 65, 467-478. [CrossRef] [PubMed]

338. Roza, T.H.; Lopes, S.L.S.; Passos, I.C. Cariprazine for acute mood episodes in bipolar disorder. Bipolar Disord. 2020, 22, 759-760. [CrossRef] [PubMed]

339. Findlay, L.J.; El-Mallakh, P.L.; El-Mallakh, R.S. Cariprazine for the treatment of bipolar disorder. Perspect. Psychiatr. Care 2017, 53, 148-155. [CrossRef]

340. Poweleit, E.A.; Colestock, M.; Kantemneni, E.C.; Strawn, J.R.; Patino, L.R.; DelBello, M.P.; Ramsey, L.B. Cariprazine in youth with bipolar and psychotic disorders: A retrospective chart review. J. Child Adolesc. Psychopharmacol. 2020, 30, 267-272. [CrossRef]

341. Earley, W.; Durgam, S.; Lu, K.; Debelle, M.; Laszlovszky, I.; Vieta, V.; Yatham, L.N. Tolerability of cariprazine in the treatment of acute bipolar I mania: A pooled post hoc analysis of 3 phase II/III studies. J. Affect. Disord. 2017, 215, 205-212. [CrossRef]

342. Ragguett, R.; McIntyre, R.S. Cariprazine for the treatment of bipolar depression: A review. Expert Rev. Neurother. 2019, 19, 317-323. [CrossRef]

343. Chhatlani, A.; Farheen, S.A.; Setty, M.J.; Tampi, R. Use of cariprazine in psychiatric disorders: A systematic review. Ann. Clin. Psychiatry 2018, 30, 326-334. [PubMed]

344. Earley, W.; Durgam, S.; Lu, K.; Ruth, A.; Németh, G.; Laszlovszky, I.; Yatham, L.N. Clinically relevant response and remission outcomes in cariprazine-treated patients with bipolar I disorder. J. Affect. Disord. 2018, 226, 239-244. [CrossRef] [PubMed]

345. Yatham, L.N.; Vieta, E.; McIntyre, R.S.; Jain, R.; Patel, M.; Earley, W. Broad efficacy of cariprazine on depressive symptoms in bipolar disorder and the clinical implications. Prim. Care Companion CNS Disord. 2020, 22, 24841. [CrossRef] [PubMed]

346. Saraf, G.; Pinto, J.V.; Yatham, L.N. Efficacy and safety of cariprazine in the treatment of bipolar disorder. Expert Opin. Pharmacother. 2019, 20, 2063-2072. [CrossRef] [PubMed]

347. Vieta, E.; Calabrese, J.R.; Whelan, J.; Tohen, M.; Earley, W.R. The efficacy of cariprazine on function in patients with bipolar depression: A post hoc analysis of a randomized controlled trial. Curr. Med. Res. Opin. 2021, 37, 1635-1643. [CrossRef] [PubMed]

348. Durgam, S.; Earley, W.; Lipschitz, A.; Guo, H.; Laszlovszky, I.; Németh, G.; Vieta, E.; Calabrese, J.R.; Yatham, L.N. An 8-week randomized, double-blind, placebo-controlled evaluation of the safety and efficacy of cariprazine in patients with bipolar I depression. Am. J. Psychiatry 2016, 173, 271-281. [CrossRef] [PubMed]

349. Pinto, J.V.; Saraf, G.; Vigo, V.; Keramatian, K.; Chakrabarty, T.; Yatham, L.N. Cariprazine in the treatment of bipolar disorder: A systematic review and meta-analysis. Bipolar Disord. 2020, 22, 360-371. [CrossRef]

350. Sanford, M.; Keating, G.M. Quetiapine: A review of its use in the management of bipolar depression. CNS Drugs 2012, 26, 435-460. [CrossRef]

351. Lei, D.; Li, W.; Tallman, M.J.; Patino, L.R.; McNamara, R.K.; Strawn, J.R.; Klein, C.C.; Nery, F.G.; Fleck, D.E.; Qin, K.; et al. Changes in the brain structural connectome after a prospective randomized clinical trial of lithium and quetiapine treatment in youth with bipolar disorder. Neuropsychopharmacology 2021, 46, 1315-1323. [CrossRef]

352. Lai, J.; Lu, Q.; Huang, T.; Hu, S.; Xu, Y. Convulsive syncope related to a small dose of quetiapine in an adolescent with bipolar disorder. Neuropsychiatr. Dis. Treat. 2017, 13, 1905-1908. [CrossRef]

353. Masi, G.; Milone, A.; Stawinoga, A.; Veltri, S.; Pisano, S. Efficacy and safety of risperidone and quetiapine in adolescents with bipolar II disorder comorbid with conduct disorder. J. Clin. Psychopharmacol. 2015, 35, 587-590. [CrossRef] [PubMed]

354. Muneer, A. Pharmacotherapy of bipolar disorder with quetiapine: A recent literature review and an update. Clin. Psychopharmacol. Neurosci. 2015, 13, 25-35. [CrossRef] [PubMed]

355. Gonzalez-Pinto, A.; Gonzalez, C.; Enjuto, S.; Fernandez de Corres, B.; Lopez, P.; Palomo, J.; Gutierrez, M.; Mosquera, F.; de Heredia, J.L.P. Psychoeducation and cognitive-behavioral therapy in bipolar disorder: An update. Acta Psychiatr. Scand. 2004, 109, 83-90. [CrossRef] [PubMed]

356. Henken, H.T.; Kupka, R.W.; Draisma, S.; Lobbestael, J.; van den Berg, K.; Demacker, S.M.A.; Regeer, E.J. A cognitive behavioural group therapy for bipolar disorder using daily mood monitoring. Behav. Cogn. Psychother. 2020, 48, 515-529. [CrossRef] 
357. Chiang, K.J.; Tsai, J.C.; Liu, D.; Lin, C.H.; Chiu, H.L.; Chou, K.R. Efficacy of cognitive-behavioral therapy in patients with bipolar disorder: A meta-analysis of randomized controlled trials. PLoS ONE 2017, 12, e0176849. [CrossRef]

358. Deckersbach, T.; Eisner, L.; Sylvia, L. Cognitive behavioral therapy for bipolar disorder. In The Massachusetts General Hospital Handbook of Cognitive Behavioral Therapy; Petersen, T.J., Sprich, S.E., Wilhelm, S., Eds.; Humana Press: Totowa, NJ, USA; Springer Nature: Berlin, Germany, 2016; pp. 87-103.

359. Lam, D.H.; Hayward, P.; Watkins, E.R.; Wright, K.; Sham, P. Relapse prevention in patients with bipolar disorder: Cognitive therapy outcome after 2 years. Am. J. Psychiatry 2005, 162, 324-329. [CrossRef]

360. Ye, B.; Jiang, Z.; Li, X.; Cao, B.; Cao, L.; Lin, Y.; Xu, G.; Miao, G. Effectiveness of cognitive behavioral therapy in treating bipolar disorder: An updated meta-analysis with randomized controlled trials. Psychiatry Clin. Neurosci. 2016, 70, 351-361. [CrossRef]

361. Scott, J.; Colom, F. Gaps and limitations of psychological interventions for bipolar disorders. Psychother. Psychosom. 2008, $22,4-11$. [CrossRef]

362. Scott, J.; Paykel, E.; Morriss, R.; Bentall, R.; Kinderman, P.; Johnson, T.; Abbott, R.; Hayhurst, H. Cognitive-behavioral therapy for severe and recurrent bipolar disorders: Randomized controlled trial. Br. J. Psychiatry 2006, 188, 313-320. [CrossRef]

363. Gregory, V. Cognitive-Behavioral therapy for depression in bipolar disorder: A meta-analysis. J. Evid. Based Soc. Work 2010, 7 , 269-279. [CrossRef]

364. Cuijpers, P.; Noma, H.; Karyotaki, E.; Cipriani, A.; Furukawa, T.A. Effectiveness and acceptability of cognitive behavior therapy delivery formats in adults with depression. JAMA Psychiatry 2019, 76, 700-707. [CrossRef] [PubMed]

365. Kimura, Y.; Hamatani, S.; Matsumoto, K.; Shimizu, E. Cognitive behavioral therapy for three patients with bipolar II disorder during depressive episodes. Case Rep. Psychiatry 2020, 2020, 3892024. [CrossRef] [PubMed]

366. Costa, R.T.; Cheniaux, E.; Rosaes, P.A.; Carvalho, M.R.; Freire, R.C.; Versiani, M.; Rangé, B.P.; Nardi, A.E. The effectiveness of cognitive behavioral group therapy in treating bipolar disorder: A randomized controlled study. Braz. J. Psychiatry 2011, 33 , 144-149. [CrossRef] [PubMed]

367. Pjrek, E.; Friedrich, M.E.; Cambioli, L.; Dold, M.; Jäger, F.; Komorowski, A.; Lanzenberger, R.; Kasper, S.; Winkler, D. The efficacy of light therapy in the treatment of seasonal affective disorder: A metaanalysis of randomized controlled trials. Psychother. Psychosom. 2020, 89, 17-24. [CrossRef] [PubMed]

368. Bais, B.; Kamperman, A.M.; Bijma, H.H.; Hoogendijk, W.J.; Souman, J.L.; Knijff, E.; Lambregtse-van den Berg, M.P. Effects of bright light therapy for depression during pregnancy: A randomised, double-blind controlled trial. BMJ Open 2020, 10, e038030. [CrossRef] [PubMed]

369. Onega, L.L.; Pierce, T.W. Use of bright light therapy for older adults with dementia. BJPsych. Adv. 2020, 26, 221-228. [CrossRef]

370. Johansson, V.; Kuja-Halkola, R.; Cannon, T.D.; Hultman, C.M.; Hedman, A.M. A population-based heritability estimate of bipolar disorder-In a Swedish twin sample. Psychiatry Res. 2019, 278, 180-187. [CrossRef]

371. McGuffin, P.; Rijsdijk, F.; Andrew, M.; Sham, P.; Katz, R.; Cardno, A. The heritability of bipolar affective disorder and the genetic relationship to unipolar depression. Arch. Gen. Psychiatry 2003, 60, 497-502. [CrossRef]

372. Evans, M.; Rohan, K.J.; Sitnikov, L.; Mahon, J.N.; Nillni, Y.I.; Lindsey, K.T.; Vacekc, P.M. Cognitive change across cognitivebehavioral and light therapy treatments for seasonal affective disorder: What accounts for clinical status the next winter? Cognit. Ther. Res. 2013, 37, 1201-1213. [CrossRef]

373. Knapen, S.E.; van de Werken, M.; Gordijn, M.C.M.; Meesters, Y. The duration of light treatment and therapy outcome in seasonal affective disorder. J. Affect. Disord. 2014, 166, 343-346. [CrossRef]

374. Maruani, J.; Geoffroy, P.A. Bright light as a personalized precision treatment of mood disorders. Front. Psychiatry 2019, 10, 85 [CrossRef] [PubMed]

375. Takeshima, M.; Utsumi, T.; Aoki, Y.; Wang, Z.; Suzuki, M.; Okajima, I.; Watanabe, N.; Watanabe, K.; Takaesu, Y. Efficacy and safety of bright light therapy for manic and depressive symptoms in patients with bipolar disorder: A systematic review and meta-analysis. Psychiatry Clin. Neurosci. 2020, 74, 247-256. [CrossRef]

376. Nasr, S.J.; Elmaadawi, A.Z.; Patel, R. Bright light therapy for bipolar depression. Curr. Psychiatry 2018, 17, 28-32.

377. Geoffroy, P.A.; Schroder, C.M.; Bourgin, P. Light treatment in depression: An antique treatment with new insights. Sleep Med. Rev. 2018, 40, 218-219. [CrossRef] [PubMed]

378. Al-Karawi, D.; Jubair, L. Bright light therapy for nonseasonal depression: Meta-analysis of clinical trials. J. Affect. Disord. 2016, 198, 64-71. [CrossRef] [PubMed]

379. Mårtensson, B.; Pettersson, A.; Berglund, L.; Ekselius, L. Bright white light therapy in depression: A critical review of the evidence. J. Affect. Disord. 2015, 182, 1-7. [CrossRef]

380. Perera, S.; Eisen, R.; Bhatt, M.; Bhatnagar, N.; de Souza, R.; Thabane, L.; Samaan, Z. Light therapy for non-seasonal depression: Systematic review and meta-analysis. BJPsych. Open 2016, 2, 116-126. [CrossRef]

381. Tseng, P.T.; Chen, Y.W.; Tu, K.Y.; Chung, W.; Wang, H.Y.; Wu, C.K.; Lin, P.Y. Light therapy in the treatment of patients with bipolar depression: A meta-analytic study. Eur. Neuropsychopharmacol. 2016, 26, 1037-1047. [CrossRef]

382. Fries, G.R.; Zamzow, M.J.; Andrews, T.; Pink, O.; Scaini, G.; Quevedo, J. Accelerated aging in bipolar disorder: A comprehensive review of molecular findings and their clinical implications. Neurosci. Biobehav. Rev. 2020, 112, 107-116. [CrossRef]

383. Sit, D.; McGowan, J.; Wiltrout, C.; Weingarden, J.; Diler, R.S.; Dills, J.L.; Luther, J.F.; Seltman, H.; Terman, M.; Wisniewski, S.; et al A randomized, placebo-controlled trial of light therapy for bipolar depression: Antidepressant efficacy, side effects, changes in suicidality and sleep. Biol. Psychiatry 2015, 77, 66S. 
384. Sit, D.K.; McGowan, J.; Wiltrout, C.; Diler, R.S.; Dills, J.; Luther, J.; Yang, A.; Ciolino, J.D.; Seltman, H.; Wisniewski, S.; et al. Adjunctive bright light therapy for bipolar depression: A randomized double-blind placebo-controlled trial. Am. J. Psychiatry 2018, 175, 131-139. [CrossRef]

385. Desautels, C.; Savard, J.; Ivers, H. Moderators of cognitive therapy and bright light therapy effects on depressive symptoms in patients with breast cancer. Int. J. Behav. Med. 2019, 26, 380-390. [CrossRef] [PubMed]

386. Lam, R.W.; Teng, M.Y.; Jung, Y.E.; Evans, V.C.; Gottlieb, J.F.; Chakrabarty, T.; Michalak, E.E.; Murphy, J.K.; Yatham, L.N.; Sit, D.K. Light therapy for patients with bipolar depression: Systematic review and meta-analysis of randomized controlled trials. Can. J. Psychiatry 2020, 65, 290-300. [CrossRef] [PubMed]

387. Geoffroy, P.A.; Schroder, C.M.; Reynaud, E.; Bourgin, P. Efficacy of light therapy versus antidepressant drugs, and of the combination versus monotherapy, in major depressive episodes: A systematic review and meta-analysis. Sleep Med. Rev. 2019, 48, 101213. [CrossRef]

388. Kupeli, N.Y.; Bulut, N.S.; Bulut, G.C.; Kurt, E.; Kora, K. Efficacy of bright light therapy in bipolar depression. Psychiatry Res. 2018, 260, 432-438. [CrossRef]

389. Benedetti, F.; Avery, D.H.; Bauer, M.; Bunney, W.E.; Caliyurt, O.; Camardese, G.; Colombo, C.; Dallaspezia, S.; Henriksen, T.E.; Kasper, S.; et al. Evidence for the efficacy of bright light therapy for bipolar depression. Am. J. Psychiatry 2018, 175, 905-906. [CrossRef] [PubMed]

390. Hirakawa, H.; Terao, T.; Muronaga, M.; Ishii, N. Adjunctive bright light therapy for treating bipolar depression: A systematic review and meta-analysis of randomized controlled trials. Brain Behav. 2020, 10, 1-12. [CrossRef]

391. Zhou, T.H.; Dang, W.M.; Ma, Y.T.; Hu, C.Q.; Wang, N.; Zhang, G.Y.; Wang, G.; Shi, C.; Zhang, H.; Guo, B.; et al. Clinical efficacy, onset time and safety of bright light therapy in acute bipolar depression as an adjunctive therapy: A randomized controlled trial. J. Affect. Disord. 2018, 227, 90-96. [CrossRef]

392. Holmes, E.A.; Hales, S.A.; Young, K.; Di Simplicio, M. Imagery-Based Cognitive Therapy for Bipolar Disorder and Mood Instability; Guilford Press: New York, NY, USA, 2019.

393. Hales, S.A.; Di Simplicio, M.; Iyadurai, L.; Blackwell, S.E.; Young, K.; Fairburn, C.G.; Geddes, J.R.; Goodwin, G.M.; Holmes, E.A Imagery-focused cognitive therapy (ImCT) for mood instability and anxiety in a small sample of patients with bipolar disorder: A pilot clinical audit. Behav. Cogn. Psychother. 2018, 46, 706-725. [CrossRef] [PubMed]

394. Versiani, M.; Cheniaux, E.; Landeira-Fernandez, J. Efficacy and safety of electroconvulsive therapy in the treatment of bipolar disorder: A systematic review. J. ECT 2011, 27, 153-164. [CrossRef]

395. Liebman, L.S.; Ahle, G.M.; Briggs, M.C.; Kellner, C.H. Electroconvulsive therapy and bipolar disorder. In The Bipolar Book: History, Neurobiology, and Treatment; Yildiz, A., Ruiz, P., Nemeroff, C.B., Eds.; Oxford University Press: Oxford, UK, 2015 ; pp. 367-375.

396. Lv, Q.; Hu, Q.; Zhang, W.; Huang, X.; Zhu, M.; Geng, R.; Cheng, X.; Bao, C.; Wang, Y.; Zhang, C.; et al. Disturbance of oxidative stress parameters in treatment-resistant bipolar disorder and their association with electroconvulsive therapy Response. Int. J. Neuropsychopharmacol. 2020, 23, 207-216. [CrossRef]

397. Başgül, Ş.S.; Luş, M.G.; Hashimov, A. Electroconvulsive therapy in an adolescent with bipolar disorder, substance use, and body dysmorphic disorder comorbidity: Case report. Neurocase 2020, 26, 51-54. [CrossRef]

398. Schoeyen, H.K.; Kessler, U.; Andreassen, O.A.; Auestad, B.H.; Bergsholm, P.; Malt, U.F.; Morken, G.; Oedegaard, K.J.; Vaaler, A. Treatment-resistant bipolar depression: A randomized controlled trial of electroconvulsive therapy versus algorithm based pharmacological treatment. Am. J. Psychiatry 2015, 172, 41-51. [CrossRef]

399. Perugi, G.; Medda, P.; Toni, C.; Mariani, M.G.; Socci, C.; Mauri, M. The role of Electroconvulsive Therapy (ECT) in bipolar disorder: Effectiveness in 522 patients with bipolar depression, mixed-state, mania and catatonic features. Curr. Neuropharmacol. 2017, 15, 359-371. [CrossRef]

400. Fink, M.; Kellner, C.H.; McCall, W.V. The role of ECT in suicide prevention. J. ECT 2014, 30, 5-9. [CrossRef]

401. Liang, C.; Chung, C.; Ho, P.; Tsai, C.; Chien, W. Superior anti-suicidal effects of electroconvulsive therapy in unipolar disorder and bipolar depression. Bipolar Disord. 2018, 20, 539-546. [CrossRef] 